\title{
LOS INTERESES DE LOS BANQUEROS BRITÁNICOS EN ESPAÑA: LA BANCA BARING Y SU PUGNA CON LOS ROTHSCHILD POR EL CONTROL DEL MERCURIO DE ALMADÉN
}

\author{
por \\ INÉS ROLDÁN DE MONTAUD \\ CSIC / Universidad de Alcalá
}

RESUMEN: En este artículo se estudian las circunstancias en que la Banca Baring de Londres se interesó por las finanzas españolas a mediados del siglo XIX, así como la pugna que mantuvo con los Rotbscbild, los tradicionales banqueros del Gobierno, por el control del mercurio de Almadén. No faltaron a los Baring las simpatías de algunos ministros de Hacienda como Mon o Bravo Murillo que procuraron, infructuosamente, romper el vínculo de dependencia establecido con Rotbscbild desde 1834. Elaborado utilizando documentación procedente de los archivos de ambas bancas en Londres, proporciona información sobre el mundo financiero madrileño de mediados de siglo, en especial sobre algunas entidades todavía poco conocidas como el Banco de Ultramar o el Banco del Fomento, así como sobre diversos banqueros particulares entre otros, los O'Shea, agentes de Baring en Madrid.

PAlabras Clave: Historia financiera. Hacienda Pública. España. Mercurio. Almadén. Baring. Rothschild. O'Shea. Mon. Bertrán de Lis. Bravo Murillo. Banco de Fomento y U1tramar.

ABSTRACT: This article studies the circumstances under which Baring's Bank, in London, became involved in Spanish finance in the middle of the nineteenth century, and the struggle between these bankers and the Rothschilds, traditional bankers of the government, over the mercury of Almadén. Baring's did not lack the support of some members of the government, including Bravo Murillo, who attempted in vain to break the links of dependency established with the Rotbschilds since 1834. Using documents from both banks in London, the article presents information about the financial world of Madrid in the mid-nineteenth century, especially concerning

Hispania, LXIII/1, núm. 213 (2003) 255-294 
organizations so little known as the Banco de Ultramar and Fomento, as well as on various individual bankers like O'Shea, agents of Baring's in Madrid.

KEY WORDS: Finantial History. Public Finances. Spain. Quicksilver. Almadén. Baring. Rothschild. O'Shea. Mon. Bertrán de Lis. Bravo Murillo. Banco de Fomento y Ultramar.

\section{INTRODUCCIÓN ${ }^{1}$}

Son numerosos los autores que se han interesado por el estudio de las finanzas del Estado español decimonónico. Diversas investigaciones han centrado su atención en el problema de la deuda pública y su crecimiento, así como en la forma en que los sucesivos gabinetes intentaron hacer frente a la permanente insuficiencia de las rentas públicas. El angustioso requerimiento de recursos llevó a los responsables de la Hacienda a depender de diversos banqueros privados, que buscaron ávidamente sólidas garantías para realizar sus anticipos a un Estado de crédito dudoso. Entre las distintas rentas del Estado, el mercurio producido por las minas de Almadén fue una de las que con mayor tenacidad persiguieron los prestamistas.

La explotación del mineral de cinabrio para obtener mercurio, entonces insustituible en el tratamiento metalúrgico de los minerales de oro y plata por amalgamación, venía proporcionado al Tesoro público importantes ingresos. La independencia de las colonias americanas y el inmediato desquiciamiento del mercado del azogue obligaron a los responsables de la Hacienda a abandonar la tradicional comercialización directa del metal ${ }^{2}$. La situación se hizo cada vez más insostenible y en 1830 el Gobierno decidió vender el azogue en pública subasta. La casa Iñigo Ezpeleta y Compañía de Burdeos se comprometió entonces a hacerse cargo de todo el mercurio que se produjese, unos 20.000 quintales anuales ${ }^{3}$. En febrero de 1835 el control de las ventas de mercurio de $\mathrm{Al}$ madén pasó a manos de los Rothschild, que en aquellos años extendían su influencia en la Península y se convertían en banqueros del Estado ${ }^{4}$. Tres años

\footnotetext{
1 Esta investigación se ha realizado en el marco del programa Ramón y Cajal y del Proyecto de Investigación BHA2002-03 (MCyT).

Como unidades monetarias se emplean el peso fuerte, el real de vellón y la libra esterlina. La libra equivalía a cinco pesos; el peso a veinte reales.

2 ZaRraluQUi MARTíneZ, J.: Los almadenes de azogue: (Minas de cinabrio): La historia frente a la tradición, Madrid, Librería Internacional de Romo, 1934, pp. 694 y ss. Véase también NADAL, J.: El fracaso de la Revolución industrial en España, 1814-1913, Barcelona, Ariel, 1975, pp. 109-110.

3 Sobre las condiciones de esta contrata consúltese MARTín MARTín, V.: Los Rotbschild y las minas de Almadén, (El servicio de la deuda pública en española y la comercialización del mercurio de Almadén, Madrid, Instituto de Estudios Fiscales, 1980, p. 190.

${ }^{4}$ La penetración inicial de los Rothschild en España en OTAZU, A.: Los Rotbschild y sus socios en España (1820-1850), O. Hs. Ediciones, Madrid, 1987, Más recientemente, el trabajo de FERGUSON, 
más tarde volvían a contratar el monopolio de la venta por espacio de otros cinco años. En 1843 se alzaron, una vez más, con la contrata para la venta del mercurio que se produjera hasta $1847^{5}$.

Entre 1847 y 1850 se plantearon nuevamente cambios importantes en la forma en que el Gobierno español gestionaba la venta del azogue. Diversas circunstancias contribuyeron a alterar, una vez más, la situación de los mercados y originaron una caída de los precios: mientras la guerra en México cerraba una de las principales áreas de consumo del metal, se descubrían y ponían en explotación nuevos yacimientos de cinabrio en California. En semejante coyuntura la subasta pública se demostró impracticable por falta de licitadores, y el Gobierno se vio forzado a recurrir a nuevos procedimientos para enajenar el metal tales como la venta en comisión, convenida por vez primera en el contrato firmado con la casa Rothschild en $1852^{6}$. A esta nueva fórmula, que se prolongó hasta 1857 , se llegó únicamente después de muchas vacilaciones. Mientras tanto, entre los años 1847 y 1850, con la ilusión puesta en una mejora del mercado que permitiera volver a la subasta, el Gobierno se limitó a negociar una serie de anticipos con garantía de mercurios y evitó enajenar el producto. Fue precisamente en este momento cuando Baring Brothers \& Co., una prominente firma de comerciantes banqueros de la City, se interesó por el negocio de azogues de la Península, abriéndose desde aquel momento un nuevo escenario donde compitieron dos de las más destacadas casas de banca europeas del XIX.

Las páginas que siguen se ocupan de la breve incursión de los Baring como agentes financieros del Gobierno entre 1848 y 1850 . Es cierto que no consiguieron adquirir una destacada posición como prestamistas del Estado; pese a ello merece la pena prestar atención a las breves relaciones entabladas con estos banqueros por cuanto muestran un intento por parte de los sucesivos gabinetes de limitar la dependencia de los Rothschild. Las circunstancias económicas y financieras de los años finales de la década de los cuarenta desalentaron a aquellos banqueros, que operaban preferentemente en los Estados Unidos y Rusia. El estudio de las relaciones de los Baring con las finanzas españolas ha permitido realizar una breve aproximación al mundo de los negocios del Madrid de mediados del XIX y, en especial, a algunas de las entidades financieras del momento todavía poco conocidas tales como el Banco de Fomento y Ultramar y el de la Unión.

Este artículo no pretende ser, en modo alguno, un estudio del mercurio de Almadén ni de sus vinculaciones con la casa Rothschild, abordado hace ya años por Martín Martín. Ha sido posible gracias a la utilización de los fondos conservados en los archivos de las bancas Baring Brothers \& Co. y Rothschild \&

N.: The World's Banker. The History of the House of Rothschild, Weidenfield \& Nicolson, Londres, 1998, especialmente pp. 375 y ss.

s ZARRALUQUI, J.: Los almadenes..., p. 698

${ }^{6}$ NADAL, J.: El fracaso..., pp. 119-110. 
Sons Ltd. de Londres ${ }^{7}$. La documentación que custodian aporta información de primera mano - la correspondencia cruzada entre los diversos socios de una entidad comercial-, que completa la documentación del Ministerio de Hacienda (Archivo Histórico Nacional) y la consular (Archivo del Ministerio de Asuntos Exteriores), así como la existente en el Public Record Office en Kew Gardens.

\section{LOS PRIMEROS CONTACTOS}

Procedentes de Bremen, los Baring se habían asentado en Exeter a principios del siglo XVIII, dedicándose a la manufactura y comercialización de los paños de lana. En breve abrían casa en Londres bajo la razón social John \& Francis Baring \& Co. Interesados en la mayoría de los grandes renglones comerciales del período, especialmente el té, azúcar, café, índigo y algodón, fue a raíz de la financiación de los aliados europeos de Gran Bretaña contra la Francia revolucionaria, entre 1796 y 1814, cuando la firma emergió como uno de los más poderosos establecimientos de la banca comercial europea, contribuyendo a hacer de Inglaterra una gran potencia mercantil. Los Baring no tardaron en percibir las ilimitadas posibilidades que surgían al otro lado del Atlántico. Desde fechas tempranas establecieron una agencia en Filadelfia y financiaron la compra de la zona del Mississippi a Francia en $1802^{8}$.

Parece que en el siglo XVIII los Baring tuvieron alguna conexión con España, especialmente con los puertos comerciales de Cádiz y Barcelona ${ }^{9}$. Tenemos noticias de que a fines de siglo Charles Baring viajó por la Península y estableció, tanto en España como en Portugal, una serie de relaciones poco afortunadas. Algo después, en 1799 los Baring rehusaban tomar parte en el traspaso de plata de las colonias americanas hacia España, entonces en guerra con Inglaterra, a pesar de que se trataba de un negocio muy lucrativo ${ }^{10}$. A lo largo del XIX las relaciones fueron esporádicas. Con fuertes vinculaciones en Rusia, en el resto de Europa la casa Baring tuvo intereses relativamente limita$\operatorname{dos}^{11}$. España y Portugal quedaron fuera de su ámbito de operaciones, salvo en

7 Estoy en deuda con ambas entidades bancarias por haber facilitado mi acceso a sus archivos. Agradezco a John Orbell y Serena Kelly, de Baring Brothers Archive, y a Victor Grey y Melanie Aspey, de Rothschilds Archive, todo el apoyo prestado durante la etapa en que trabajé con la documentación que custodian.

8. Sobre los Baring consúltese, entre otros, JenKs, L. H.: The Migration of British Capital to 1875, Londres, Camelot Press, 1971, pp. 33 y ss; Wechsberg, J.: The Merchant Bankers, Londres, 1967, cap. III. De carácter monográfico: HIDY, R.W.: The House of Baring in American Trade and Finance. English Merchant Bankers at Work 1763-1865, Harvard University Press, 1949; ORBELL, J.: Baring Brothers $\&$ Co., Limited. A History to 1939, Londres, Baring Brothers \& Co., 1985, y ZIEGLER, P.: The Sixth Great Power. Barings, 1768-1929, Londres, William Collins Sons \& Co., 1988.

9. ORBell, J.: Baring Brothers..., p. 4.

10 ZIEGLER, P.: The Sixth great..., p. 22.

11 ORBELL, J.: Baring Brothers..., p. 43.

Hispania, LXIII/1, núm. 213 (2003) 255-294 
ocasionales y contados episodios. No es de extrañar que en 1834 se mantuvieran al margen del empréstito del Conde de Toreno, que por valor de cuatro millones de esterlinas fue colocado en París por el banquero Ardoin y en Londres por Ricardo ${ }^{12}$, decisión de la que se alegraban cuando, poco después, los valores españoles se precipitaron en la Bolsa londinense ${ }^{13}$.

Si los Baring se abstenían de intervenir en los negocios peninsulares, no ocurría lo mismo en las Antillas españolas, especialmente en Cuba, donde desde principios del siglo XIX se interesaron en la comercialización del azúcar, bien por cuenta propia o en combinación con los grandes exportadores cubanos, de los cuales recibían frutos en comisión y a los que abrían líneas de crédito comercial ${ }^{14}$. El alcance de sus operaciones debió de ser de tal envergadura que llamó incluso la atención del barón Alphonse de Rothschild, que a su paso por La Habana, en enero del año 1849, escribía: «El negocio del azúcar es aquí un monopolio de los exportadores Drake, Burnham, Picard \& Albert. No obstante, la parte del león no queda en sus manos, sino en las de Baring, Coutts, Fruehling y Goschen, que son quienes realizan los mayores beneficios a través de comisiones, créditos y consignaciones. Los créditos se abren en la mayoría de los casos por cuenta de casas europeas»" 15 .

Los Baring mantuvieron estrechas relaciones con los plantadores cubanos hasta los años sesenta, cuando los mercados europeos eran definitivamente conquistados por el azúcar de remolacha. A partir de entonces languidecieron rápidamente los contactos. Fue determinante también en este proceso la paralela expansión del mercado americano, pero influyeron igualmente los trastornos ocasionados por la guerra iniciada a fines de 1868 , que no dejó de ocasionar dificultades a los comerciantes británicos. En 1866 Miguel Aldama, uno de los grandes propietarios cubanos, había consignado a Baring 2.500 cajas de azúcar, otras tantas al año siguiente. Entabladas las relaciones, los Baring le concedieron un

12 FENN, C.: Fenn on the Funds. A Compendium of the English and Foreign Funds; and the Principal Joint Stock Companies Forming an Epitome of the Various Objects of Investment Negotiable in London, Sherwood, Gilbert \& Piper, 1837, p. 581. Sobre esta operación, ARTOLA, M. La Hacienda del siglo XIX. Progresistas y moderados, Madrid, Alianza, 1986, pp. 165-166.

13 Para facilitar esta negociación de los valores en el exterior, las Cortes reconocieron en noviembre las deudas del Trienio. La cotización se disparó, pero pocos meses después, en la primera semana de mayo de 1837 , experimentaron una caída del 30 por 100 cuando el mercado comprendió que se había sobrecargado de valores extranjeros carentes de valor, DUGUiT, C.: The Story of the Stock Exchange. Its History and Position, Londres, Grant Richards, 1901, pp. 142-143.

${ }_{14}$ Baring Brothers Archive (BBA) General Ledgers, American and Colonial, 18.325, libro 18, incluye cuentas con diversos agentes cubanos desde la segunda década de siglo: James Drake a partir de 1814 (p. 261); Antonio de Frías \& Cía. desde 1815 (p. 279); Clemente Ychazu de Carricaburu desde 1814, Carricaburu, Arrieta \& Cía. (p. 113). En los años 20 se estrecharon las relaciones con Francisco Fesser, Drake, Mitchel \& Cía; en 1829 con Mariátegui, Knight \& Co. de La Habana, sus agentes más importantes en Cuba hasta los años cuarenta, BBA, 18.325 libros 25 a 31.

15 Rothschild Archive London (RAL), T8/125, 14 de enero de 1849 (Todas las citas de documentos procedentes de BBA y de RAL son traducción nuestra). 
crédito para que adquiriera una nueva propiedad azucarera. Al sobrevenir la guerra, la finca que servía de garantía al adelanto de 8.000 libras fue embargada junto al resto de las propiedades de Aldama, cuestión que motivó una serie de reclamaciones al Ministerio de Estado por parte del Gobierno británico ${ }^{16}$.

Vinculados a los banqueros franceses Hottinguer \& Co. con quienes mantenían estrechas relaciones desde 1820, los Baring se habían ocupando del suministro de tabaco a los arrendatarios franceses ${ }^{17}$. Fueron también negocios relacionados con este producto los que les atrajeron nuevamente a la Península mediado el siglo. Conviene insistir, no obstante, en que su interés en el suministro de tabaco a los contratistas que abastecían de hoja a las fábricas del Estado fue muy modesto. Probablemente carece del alcance que se le ha atribuido al afirmar que fueron los Baring quienes estuvieron detrás de Manzanedo cuando a mediados de la década comenzaba a destacar como contratista del Estado ${ }^{18}$.

A fines de 1846 la casa Baring se comprometía a adquirir en Nueva Orleans 10.990 tercios de tabaco en rama por cuenta de los contratistas, José Casals, Gaspar Remisa, José Safont, José Salamanca y José Buschental, entre otros. Todos estos personajes eran conocidos comerciantes y banqueros de la plaza de Madrid y estuvieron vinculados a la creación del Banco de Isabel II en $1844^{19}$. En representación de los contratistas, Safont había encargado la negociación del suministro al Banco de la Unión del que todos ellos èran también accionistas. Fundado en 1845, el Banco, sobre el que todavía disponemos de escasa información, tenía un capital desembolsado de 15 millones de pesetas. Su activo se elevaba a 22 millones $^{20}$. Pedro Saiglan Bagneres, su director, se puso de inmediato en contacto con los Baring. Éstos se encargarían del flete y seguro del tabaco requerido, que sería adquirido a través de su agente en Nueva Orleans ${ }^{21}$.

16 BBA, HC4.6.8, correspondencia de Burnham \& Co. de La Habana de los días 6 de septiembre de 1866, 23 de mayo y 6 de julio de 1867, y Archivo Histórico Nacional (AHN) Ultramar, leg. $754 / 1$, exp. 27 y 28.

17 BBA, HC7.20. La serie HC7.1 contiene la correspondencia cruzada con Hottinguer durante el período $1820-1903$

18 OTAZU, A.: Los Rotbschid..., p. 181. Revisada detalladamente la documentación de los Baring, parece que ésta fue la única ocasión en que dichos banqueros intervinieron directamente en el aprovisionamiento de los contratistas y Manzanedo no figuraba entonces entre ellos. Es más, los Baring no tuvieron un buen concepto del personaje ni de su socio Casares, "gente sin medios», según indicaba Thomas Baring a sus socios en una de las cartas escritas durante su estancia en Madrid en diciembre de 1849, BBA, HC1.20.4, 1 de diciembre. Es probable que Manzanedo tuviera conexiones con Mariátegui, Knight \& Co., y que fueran éstos quienes proporcionaron parte del tabaco cubano adquirido por Manzanedo cuando se hizo cargo de la contrata. Mariátegui, Knight y Co. fueron, como ya se ha dicho, los agentes más importantes de Baring en la isla y puntales en sus operaciones comerciales sobre azúcares cubanos, pero realizaban también abundantes operaciones por cuanta propia.

19 La correspondencia con Saiglan Bagneres en BBA, HC4.8.13.

20 TORTELLA, G.: Los orígenes del capitalismo en España, Madrid, Tecnos, 1973, p. 35.

21 BBA, HC4.8.13, Saiglan Bagneres a BB, 7 de diciembre de 1846. 
Casi un año más tarde, el 1 de octubre de 1847, llegaba a Madrid, donde permanecería hasta abril de 1848, Francis de Palesieux Falconet, uno de los hombres de confianza de los Baring. Debía ocuparse de recepcionar los trece buques que, en breve, arribarían a los puertos de Cádiz y La Coruña cargados de tabaco y de cobrar las 42 libranzas que habían sido entregadas a los Baring sobre el Banco de la Unión por un importe de 168.510 pesos (842.550 pesetas) ${ }^{22}$. La tirantez monetaria que entonces se extendía por las plazas comerciales, la muerte del marqués de Remisa - uno de los mayores interesados en la contrata-, sobrevenida apenas un mes después de la llegada de Falconet ${ }^{23}$, y la suspensión del Banco de la Unión contribuyeron a dificultar su misión ${ }^{24}$. La escasez de numerario era fruto de las peculiaridades propias del sistema monetario español, y se vio agravaba por la crisis financiera internacional ${ }^{25}$.

No se conocen bien las circunstancias de la desaparición del Banco, nacido como otras instituciones similares en plena etapa especulativa en 1845 . El establecimiento creado por Buschental, a juicio de Falconet un personaje de dudosa reputación, parecía tener por finalidad servir los intereses de Salamanca y del llamado partido inglés ${ }^{26}$. De ser ciertas las informaciones recabadas en me-

22 Los Baring utilizaron los servicios de Falconet en ocasiones especiales: entre 1831 y 1834 estuvo establecido, bajo la razón Falconet y Co., en Nápoles (BBA, HC1.2.1); entre 1842 y 1843 fue enviado a Buenos Aires (BBA, HC4.1.14), y desde 1847 hasta 1849 lo encontramos en Madrid (BBA, HC4.8.7). Posteriormente, desde 1851 a 1857, fue despachado a México para ocuparse de la negociación de la deuda externa (BBA, HC4.5.25).

2.3 Breve biografía de Gaspar Remisa en VICENS VIVES, J. y LlORENS, M.: Industrials $i$ polítics (segle XIX), Barcelona, 1961, pp. 311-316.

24 Las costumbres y prácticas comerciales españolas le exasperaban: «Este es el país más informal que conozco para hacer negocios. Se pierde el día entero corriendo detrás de gente que no respeta las citas. Jamás he tenido una tarea más difícil en mi vida. iDios me ayude!», BBA, HC4.8.7, Falconet a BB, nota muy confidencial sin fecha (diciembre de 1848). Durante su estancia en Madrid, Falconet disfrutó de la acogida de muchos personajes del mundo de la política y los negocios, entre otros de la reina madre "que ha sido mi amable protectora durante toda mi estancia aquí". Esta amistad se acrecentó cuando Jhosua Bates -uno de los socios de Baring- alojó en su casa de Sheen a los duques de Montpensier, obligados a abandonar Francia tras el estallido de la revolución en marzo, BBA, HC4.8.7, Falconet a Bates, 10 de marzo de 1848.

25 Sobre la naturaleza de esta crisis puede consultarse TEDDE, P.: El Banco de San Fernando, Madrid, Alianza Editorial-Banco de España, 1999, pp. 197-199.

${ }_{26}$ Es lógico que Falconet, que llegó a Madrid en el momento en que este grupo caía del poder, obtuviera pésimos informes de un personaje perseguido por Narváez en junio. Buschental fue el introductor de Salamanca en el mundo de los negocios. Ambos estuvieron asociados desde 1837 . Parece que Salamanca tuvo buenas relaciones con Palmerston, con el ministro Bulner, y que estuvo bastante vinculado con algunos hombres de negocios británicos. A principios de 1842, durante la Regencia de Espartero, y a petición del entonces ministro de Hacienda Surrá y Rull, se desplazó a Londres para negociar un arreglo de la deuda exterior del 3 por 100. La operación consistía en la capitalización de los intereses atrasados y el pago de los semestres correspondientes a 1841. Al frente de la negociación se colocó la casa Reid Irving. Salamanca tomó parte en la operación junto a José Agustín Heredia, su cuñado, y al marqués de Remisa. En aquél momento acababa de constituir con socios ingleses la compañía de Caminos de Hierro del Norte de España. En 1845 obtenía la

Hispania, LXIII/1, núm. 213 (2003) 255-294 
dios financieros madrileños por el agente de los Baring, en realidad el Banco nunca desembolsó todo su capital; como ocurrió con muchas otras entidades nacidas durante la coyuntura expansiva que precedió a la crisis del 47 , sus creadores retuvieron gran parte de las acciones con el fin de realizar un importante beneficio especulando con dichos títulos ${ }^{27}$. Confiando excesivamente en el apoyo de Salamanca que había ocupado la cartera de Hacienda el 28 de marzo de 1847 al constituirse el Ministerio Pacheco, el establecimiento se implicó en una serie de operaciones cuya liquidación se vio dificultada por la caída en octubre del Gabinete presidido por Salamanca desde el mes de agosto ${ }^{28}$.

\section{LOS BARING Y EL BANCO DE FOMENTO Y ULTRAMAR}

La presencia de Falconet en España fue aprovechada por los Baring para estudiar la posibilidad de extender sus intereses en el ámbito peninsular, en particular en el negocio del azogue. Hacía tiempo que la firma se mostraba interesada por la comercialización de este producto. En 1815 se había ocupado de vender en América 4.000 quintales de mercurio procedente de las minas de Idria adquiridos al Gobierno austríaco ${ }^{29}$. Sabemos que a principios de 1833 habían pedido a Felipe de Riera que les remitiera las condiciones de la contrata de mercurio ${ }^{30}$. Sin embargo, cuando a fines de aquel año el marqués de Casa Riera les anunciaba que la contrata (de la que se había hecho cargo Ezpeleta en 1830) estaba a punto de concluir y les aconsejaba que nombrasen una persona de confianza para que les representase ante el Gobierno ${ }^{31}$, la propuesta no pareció encontrar acogida favorable y los Baring se abstuvieron de concurrir a la subasta celebrada en febrero de 1835, a raíz de la cual la venta del mercurio pasó, como vimos, a manos de los Rothschild. Con anterioridad a dicha fecha, la casa Rothschild había estado interesada en la comercialización del azogue español. No parece, sin embargo, que en 1830 fuesen los Rothschild quienes realmente se hicieron cargo de la contrata escondidos bajo la firma Ezpeleta y Co. de Burdeos, si bien poco después llegaron a acuerdos con dicha firma para

\footnotetext{
concesión de la línea a Aranjuez en la que junto a Buschental participaban también varios capitalistas británicos. Véase HernÁNDEZ GIRBAL, F.: José de Salamanca. Marqués de Salamanca. El Montecristo Español, Madrid, Ediciones Lira, 1992, pp. $189-98198$ y p. 660, y ARTOLA M. (dir.): Los ferrocarriles en España, Madrid, Servicio de Estudios del Banco de España, 1978, vol. I, p. 242.

27 ARTOLA, M.: Los ferrocarriles..., vol. I, p. 20, ha documentado el caso del Banco del Fomento.

28 BBA, HC4.8.7, Falconet a BB, 6 y 15 de octubre de 1847.

$29 \mathrm{BBA}, \mathrm{HC} 1.1 .4$, carta fechada en Viena el 28 de noviembre de 1816.

30 BBA, HC1.1.4, Felipe Riera a BB, 24 de enero de 1833.

31 BBA, HC4.8.1, Felipe Riera a BB, 26 de diciembre de 1833.
}

Hispania, LXIII/1, núm. 213 (2003) 255-294 
compartir el negocio. Así parece desprenderse de la correspondencia cruzada entre los Rothschild de Londres y sus socios de París ${ }^{32}$.

Doce años más tarde, en abril de 1847, pocos meses antes de la llegada de Falconet a Madrid, Saiglan Bagneres informaba a los Baring de que la contrata del azogue vencía en septiembre y se prestaba a actuar en su nombre. Les anunciaba que junto a algunos amigos estaba dispuesto a participar en el negocio, en caso de que los Baring decidiesen interesarse en él. La respuesta era nuevamente negativa: dada la situación del mercado monetario y las circunstancias por las que atravesaba la república mexicana no se sentían inclinados a embarcarse en una aventura semejante. El momento de la subasta se aproximaba y no creían posible un cambio favorable en tan breve espacio de tiempo ${ }^{33}$.

Esas mismas consideraciones eran las que tenían presentes los Rothschild para retirarse provisional y prudentemente de la escena. La contrata les venía proporcionado enormes beneficios. Obtenido el mercurio a 54,5 pesos el quintal, lo habían venido vendiendo a 76 u 80 pesos en el mercado de Londres, incluso a 150 pesos a los refinadores de plata del interior de México. Según recientes estimaciones de Ferguson, durante algunos años habían obtenido beneficios de 13.000 libras esterlinas, que al aumentar la producción y elevarse los precios a partir de 1838 (Cuadro I) se convirtieron en 32.000, aproximadamente un 38 por 100 de los beneficios netos de la rama británica de los Rothschild, que ésta compartía con la francesa ${ }^{34}$. Conocedores de las nuevas condiciones del mercado y conscientes de los peligros que se avecinaban, en 1847 dejaban, como se ha dicho, el campo libre. Así fue como el 10 de junio de 1847 la contrata para la venta del mercurio español pudo ir a parar a manos del inexperto Banco de Fomento, dirigido por Francisco de las Rivas, y la sociedad El Iris, a 1.730 reales el quintal castellano 35 .

El Banco de Fomento había sido creado hacía un par de años en plena etapa especulativa. En 1845 un consorcio financiero del que formaba parte el grupo O'Shea obtuvo en pública subasta la contratación de un empréstito de 200 millones de reales, constituyéndose con dicho propósito el Banco de Fomento y Empréstito de Caminos y Canales. Según sus estatutos se dedicaría a

32 RAL, XI/109/32/2, carta de Rothschild Frères fechada en diciembre de 1833: «Hoy hemos recibido carta de Ezpeleta confirmando la oferta de sus socios de entregarnos a lo largo de 1834 y tan pronto como sea posible (...) 6.000 botellas de mercurio en Cádiz a 43,5 (...) a condición de que no se destinen al mercado de Londres. Por su parte, se comprometen a no enviar cantidad alguna a América, al menos hasta la conclusión del negocio, salvo los lotes que hayan comprometido antes de dicha fecha (...). Les hemos contestado que dábamos nuestro consentimiento por cuanto se relaciona a la casa de París». Véase también, Ferguson, N.: The world's..., p. 379.

33 BBA, HC4.8.13, Saiglan Bagneres a BB, y BBA, Letter Book (en adelante LB) núm. 17, fol. 91, BB a Bagneres, 10 de febrero de 1847 .

${ }^{34}$ Ferguson, N.: The world's..., p. 383.

35 OTAZU, M.: Los Rothschild.., pp. 253 y 254, MarTín MARTín, V.: Los Rothschild..., pp. 228232 y RAL, XI/109/59, Rothschild Frères a Daniel Weisweiller, 16 de marzo de 1847 . Sobre la Compañía General el Iris, presidida por Gaspar Remisa, véase OTAZU, A.: Los Rotbschild..., pp. 440 y 441.

Hispania, LXIII/1, núm. 213 (2003) 255-294 
la realización de empresas diversas, como el préstamo para la inversión industrial y la contratación de negocios públicos. En 1846 había proporcionado al Tesoro parte del anticipo convenido; la entrega del resto la efectuó mediante la realización de diversas obras públicas que le fueron adjudicadas con cargo a sus aportaciones. Se ocupó también de conducir los vapores correos a las Antillas ${ }^{36}$.

\section{CUADRO I \\ PRODUCCIÓN DE MERCURIO EN ESPAÑA (1830-1860)}

\begin{tabular}{cccccc}
\hline Años & Producción & $\begin{array}{c}\text { Precios de la } \\
\text { contrata (reales) }\end{array}$ & Años & Producción & $\begin{array}{c}\text { Precios de la } \\
\text { contrata (reales) }\end{array}$ \\
\hline $1830-31$ & 20,1 & 675 & $1845-46$ & 22,6 & \\
$1831-32$. & 20,1 & & $1846-47$ & 22,4 & \\
$1932-33$ & 22,0 & & $1847-48$ & 22,1 & 1.730 \\
$1833-34$ & 22,0 & & $1848-49$ & 20,9 & \\
$1834-35$ & 22,0 & & $1849-50$ & 11,8 & \\
$1835-36$ & 21,6 & 1.082 & $1850-51$ & 12,2 & 1.400 \\
$1836-37$ & 20,8 & & $1851-52$ & 15,6 & 1.300 \\
$1837-38$ & 17,5 & & $1852-53$ & 18,0 & \\
$1838-39$ & 24,8 & 1.200 & $1853-54$ & 19,3 & 658,8 \\
$1839-40$ & 23,1 & & $1854-55$ & 13,1 & \\
$1840-41$ & 18,5 & & $1855-56$ & 20,6 & 616 \\
$1841-42$ & 20,5 & & $1756-57$ & 15,1 & \\
$1842-43$ & 20,7 & & $1857-58$ & 26,7 & \\
$1843-44$ & 20,8 & 1.630 & $1858-59$ & 17,5 & \\
$1844-45$ & 21,5 & & $1859-60$ & 23,2 & \\
\hline
\end{tabular}

Fuente: L. M. Sánchez Molero, Memoria sobre azogues, Madrid, 1869, p. 192 y V. Martín Martín, Los Rotbschild y las minas de Almadén, Madrid, IEF, 1980, pp. 193, 260 y 267. Los precios de venta han sido tomados de las distintas contratas.

36 Para un estudio de sus orígenes, Memoria del Banco de Fomento y Ultramar, Madrid, Tipografía de Saavedra y Cía, 1849, e Informe de la Comisión de accionistas del Banco de Fomento y Ultramar nombrado para examinar la memoria y balance de que se dio cuenta en la Junta general de 30 de marzo de 1849, Madrid, 1849. Consúltese también: ArTOlA, M.: Los ferrocarriles..., vol. I, p. 20; BAHAMONDE MAGro, A. y OTERo CARvajal, L.E.: «La reproducción patrimonial de la elite burguesa madrileña en la Restauración. El caso de Francisco de Rivas y Ubieta, marqués de Mudela, 1834-1882», en La sociedad madrileña durante la Restauración, 1876-1931, Madrid, 1989, vol. I, pp. 537-540 y SAIZ PASTOR, C.: "La participación del sector financiero español en el negocio de la navegación trasatlántica (1827-1851)», Historia Contemporánea, 1989, núm. 2, pp. 103-117.

Hispania, LXIII/1, núm. 213 (2003) 255-294 


\section{GRÁFICO I}

PRODUCCIÖN DE MERCURIO EN ESPAÑA (1830-1860)

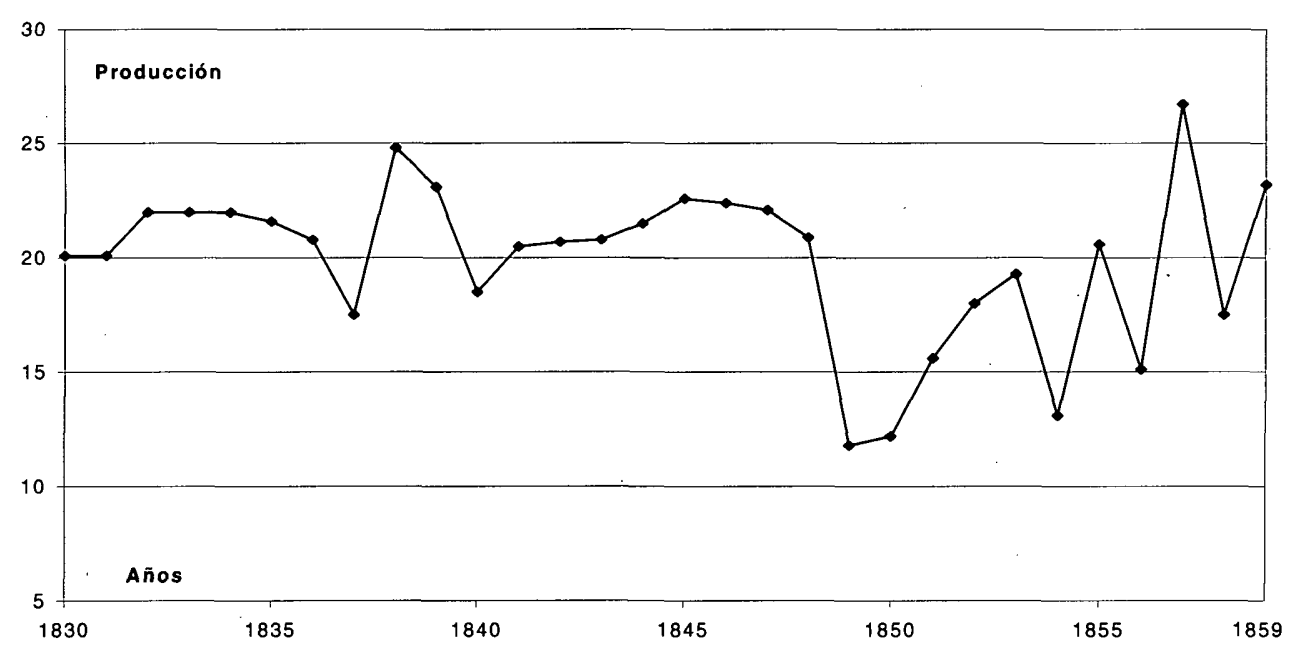

En las condiciones adversas creadas por la crisis comercial y financiera que se iniciaba en 1847 , el establecimiento encontró serias dificultades para hacer frente a su compromiso de adelantar al Tesoro 60 millones de reales a un 6 por 100 de interés, reintegrables en cinco años, tal y como se estipulaba en el pliego de condiciones de la subasta ${ }^{37}$. Los primeros 30 millones los facilitó en junio y julio. En agosto y septiembre debía entregar los restantes. En breve comenzaría a hacerse cargo de los 20.000 quintales de mercurio anuales que se había comprometido a recibir durante cinco años y necesitaba recursos para hacer frente a los crecidos gastos que llevaba aparejado el envasado, transporte y comercialización del metal entregado en Almadén. De hecho, antes de haber ingresado cantidad alguna por venta de mercurio se había visto obligado a desembolsar cerca de 34 millones de reales ${ }^{38}$.

Acuciada por la necesidad, entrado el verano de 1847, la gente del Fomento buscaba en vano el auxilio de diversos banqueros de Londres y París para reunir los millones pendientes de entrega. Francisco de las Rivas viajó personalmente a Bayona para entrevistarse con un agente de los Rothschild ${ }^{39}$. En noviembre, Antonio Jordá, su nuevo director, celebró varias reuniones igualmente infruc-

37 BBA, HC4.8.7, Falconet a BB, 21 de octubre de 1847.

38 Memoria del Banco de Fomento, ..., p. 18.

$39 \mathrm{RAL}, \mathrm{XI} / 109 / 63$, s/f (julio-septiembre de 1847), Nathaniel de Rothschild a sus hermanos en Londres, y BBA, HC4.8.7, Falconet a BB, octubre de 1847. BAHAMONDE, A., en «La reproducción... », p. 540 , menciona el viaje de de la Riva, op. cit., p. 540. 
tuosas, con Daniel Weisweiller, el agente de los Rothschild en Madrid ${ }^{40}$. Mediado el mes tornaba desesperado hacia los Baring - con quienes seguramente había entrado en contacto durante el verano- con la esperanza de que se encargasen de negociar el azogue por cuenta del establecimiento ${ }^{41}$. Los directores del Fomento acudieron también al Banco de San Fernando que se prestó a anticipar siete millones de reales garantizados con un depósito de 4.760 quintales de mercurio ${ }^{42}$. Como el anticipo no pudo ser reintegrado en el plazo convenido, el Fomento acabó cediendo al San Fernando, a 80 pesos el quintal, la partida de mercurio que servía de garantía y que había adquirido a 86 .

Es probable que la idea de recurrir a los Baring partiera de Enrique O'Shea, uno de los directores del Fomento. Vinculado a Salamanca, en 1844 había constituido con éste, Weisweller y un puñado de capitalistas, la Empresa de Tabacos de brevísima existencia ${ }^{43}$. El contacto de O'Shea con la casa británica parece remontarse a dicho año. Alejando Mon, el ministro de Hacienda del Gabinete presidido por el general Narváez, para sanear las rentas de la Hacienda proyectaba entonces una operación de conversión de la deuda flotante en consolidada al 3 por 100. Era el preludio de su trascendental reforma monetaria ${ }^{44}$. O'Shea formaba parte del grupo de capitalistas interesados en el empréstito, y en aquella ocasión se había dirigido a los Baring para saber cómo sería considerada la operación en el mercado de Londres y para invitarles a participar en el negocio. Confidencialmente, les aseguraba: «El gobierno no está dispuesto bajo ningún concepto a continuar sujeto a la tutela que le ha sido impuesta constantemente por ciertos vecinos de ustedes que han ganado sumas enormes desde que entraron en contacto con este país». Aunque carecía de autorización para hacerles una propuesta, deseaba que se establecieran las bases que permitirían a la casa prestar su concurso al Gobierno ${ }^{45}$.

Habría que esperar todavía tres años para que las relaciones de O'Shea con los Baring se tornaran más estrechas: a fines de 1847 Falconet decidía encomendar precisamente a aquéllos banqueros madrileños la remisión a Londres, mediante letras de cambio, de las cantidades que los contratistas de tabaco le iban entregando a cambio de los conocimientos de embarque de los buques que arribaban con el tabaco. El agente de los Baring se había dirigido a los O'Shea aconsejado por Juan Sevillano, marqués de Fuentes de Duero, a juicio de Falconet uno de los hombres más ricos y mejor informados de Madrid en asuntos comerciales, a la sazón corresponsal de los Baring. El marqués les había preveni-

\footnotetext{
40 Detalles sobre este acercamiento en OTAZU, A.: Los Rotbschid..., pp. 256-257.

41 BBA, HC4.8.7, Falconet a BB, 23 de noviembre de 1847.

42 Memoria del Banco de Fomento, ..., p. 21.

43 COMÍn COMín, F. y MARTín ACEÑA, P.: Tabacalera y el Estanco del tabaco en España, 16361998, Madrid, Fundación Tabacalera, 1999, p. 73.

${ }^{44}$ GARzón PARejA, M.: Historia de la Hacienda de España, Madrid, Instituto de Estudios Fiscales, 1984, vol. I, p. 980.

4s BBA, HC4.8.6, O'Shea a BB, 26 de abril de 1844.
} 
do contra el San Fernando por juzgarlo excesivamente comprometido con el Gobierno ${ }^{46}$. No le faltaba razón. Recuérdese que desde 1845 el Banco había ido suscribiendo una serie de convenios de tesorería, comprometiéndose a proporcionar los recursos para atender el gasto público mientras el Tesoro realizaba sus ingresos. En 1846 los activos del Banco contra la Hacienda ascendían a 223 millones de reales, casi cinco veces su capital desembolsado ${ }^{47}$. En tales circunstancias, Falconet compartía la opinión de que era menos arriesgado recurrir a unos banqueros privados, y Enrique O'Shea y Co. le parecían adecuados. Se iniciaba así una relación estrecha que convertió a O'Shea y Co. en agentes de Baring Brothers hasta que la crisis financiera de 1867 arrastrara a la quiebra a la firma española.

La compañía se había inscrito como casa de comercio y giro en el Registro Mercantil de Madrid en $1839^{48}$. De acuerdo con la información confidencial obtenida por los Baring, tenía en 1847 un capital que rondaba los 300.000 ó 400.000 pesos, y unos 100.000 más en fincas y propiedades urbanas. La entidad había experimentado una serie de alzas y bajas, haciéndose finalmente con la agencia de la Legión Británica y con diversas contratas del Estado. Durante mucho tiempo los O'Shea habían disfrutado prácticamente del monopolio del suministro de tabaco, actividad en la que habían actuado asociados al banquero francés Pescatore y de la que habían obtenido grandes beneficios. Enrique O'Shea conocía bien el país y tenía buenas amistades en los distintos grupos políticos españoles ${ }^{49}$.

Falconet había llegado a Madrid el 1 de octubre de 1847. Pocos días le hicieron falta para ponerse al corriente de la situación. En su carta del 7 abundaba ya en noticias sobre el mercurio y las perspectivas que rodeaban su comercialización: hasta fines de 1847 la producción debía ser entregada a los Rothschild, ya que el nuevo contrato con el Fomento no entraba en vigor hasta enero; la invasión norteamericana había paralizado el trabajo en las minas de plata mexicanas y la venta del azogue se encontraba estancada en su principal mercado. Existían, además, grandes depósitos sin vender: en manos de los Rothschild había más de 45.000 frascos. Su conclusión era que cualquier adelanto en Londres debía ser meditado cuidadosamente ${ }^{50}$. Percibía con claridad la evolución del mercado mexicano, paralizado momentáneamente, como muestran los datos proporcionados por Sánchez Molero: si en 1847 México importó 9.500 quintales, en 1848 absorbió sólo 2.600. Al año siguiente, únicamente $1.400^{51}$.

A tenor de los comentarios de Falconet, es muy probable que Antonio Jordá hubiese entrado en contacto con los Baring durante el verano y que el des-

46 BBA, HC4.8.7, 29 de octubre de 1847.

47 Artola, M.: La Hacienda..., p. 225, TEDde, P.: El banco..., pp. 168-169 y 188.

${ }_{48}$ Sobre los orígenes de la razón social, MARTín ACEÑA, P.: La creación de sociedades en Madrid 1830-1848. Un análisis del primer registro mercantil, Madrid, Fundación Empresa Publica, Programa de Historia Económica, Documento de trabajo, 9303, 1993, p. 48.

49 BBA, HC1.6.22, Statement of the Principal Firms of Madrid, Their Means and Character, abril 1848.

so BBA, HC4.8.7, Falconet a BB, 7 de octubre de 1847.

51 Memoria sobre azogues, Madrid, Imprenta de la Viuda de Antonio Jenes, 1859, p. 192.

Hispania, LXIII/1, núm. 213 (2003) 255-294 
plazamiento de su agente a Madrid tuviera por finalidad, además de ocuparse de los cargamentos de tabaco, estudiar in situ la propuesta del Banco de Fomento. Tras la llegada de Falconet a Madrid se inició una negociación de varios meses de duración. Se entrecruzaron propuestas y contra propuestas, hasta que el día 22 de diciembre el agente de los Baring envió a Londres una tercera propuesta del Fomento ${ }^{52}$. Conforme a las bases sugeridas por el Banco, los Baring se harían cargo de la venta del mercurio en ciertas condiciones: se comprometerían a adelantar 80.000 libras a la firma del contrato, y 120.000 más durante el año 1848; la cantidad sería reembolsada a lo largo de 1849 y 1850; obtendrían una comisión de un 2,5 por 100 sobre el precio de venta y sobre las cantidades anticipadas un interés superior en un 2 por 100 al tipo fijado por el Banco de Inglaterra ${ }^{53}$.

La propuesta del Banco del Fomento abría una ocasión magnífica para que la firma londinense penetrara en el mundo de los negocios españoles que desde la conclusión de la guerra carlista venía atravesando una etapa expansiva, y que se presentaba pletórico de posibilidades. De convertirse los Baring en agentes de los contratistas del mercurio, era evidente que gran parte de las transacciones realizadas en Londres por cuenta española irían también a parar irremisiblemente a sus manos, más aun teniendo en cuenta que la última crisis que había sacudido a la City había conducido a la quiebra de la importantísima firma Reid Irving y había golpeado severamente el crédito de algunos de los principales corresponsales y agentes de las casas peninsulares. En tales circunstancias era preciso reconstruir todo el complejo tejido de relaciones comerciales ${ }^{54}$.

Por otra parte, la importancia del negocio del mercurio no se limitaba a los beneficios que derivaban de la comercialización del producto en sí mismo; la posesión de la contrata proporcionaba una sólida garantía que permitía realizar con seguridad toda una serie de operaciones financieras con el Gobierno. Por ejemplo, podían tomarse libranzas sobre Manila o La Habana con toda confianza, a condición de que fueran admitidas en pago del mercurio en caso de no ser satisfechas a su vencimiento, como de hecho venía ocurriendo con frecuencia. Falconet no ignoraba que las circunstancias de la Hacienda española habían mejorado y que ya no eran posibles operaciones tan lucrativas como las realizadas hacía unos años por los Rothschild. No obstante, reconocía que todavía había mucho por hacer: el dividendo semestral de la deuda exterior del 3 por 100 debía ser pagado puntualmente y el arreglo de la deuda tendría que realizarse tarde o temprano. La casa que tuviera la contrata cuando llegara el momento estaría en posición privilegiada para hacerse con estas operaciones ${ }^{55}$. Pese a tan halagüeñas perspectivas, los Baring trataban de sopesar bien sus movimientos y los riesgos de extender su acción a un país donde apenas habían

52 BBA, LB, núm. 18, p. 19, 26 de abril de 1848, y p. 46, 6 de mayo de 1848 , cartas de BB a Antonio Jordá, y HC4.8.7, Falconet a BB, 22 de diciembre de 1847.

53 BBA, HC4.8.7, Falconet a BB, 22 de diciembre de 1847.

51 BBA, HC4.8.7, Falconet a BB, 4 de enero de 1848.

ss BBA, HC4.8.6, O'Shea a BB, 9 de abril de 1849.

Hispania, LXIII/1, núm. 213 (2003) 255-294 
operado, en el que no disponían de grandes contactos, y que, además, era tenido por feudo de los Rothschild.

Rechazadas las condiciones propuestas por el Fomento; en diciembre proseguía un farragoso proceso de negociación que puede seguirse detalladamente a través de la correspondencia de Falconet ${ }^{56}$. En enero de 1848, una vez que se hicieron cargo del mercurio, ansiosos por llegar a un acuerdo, los directores del Banco consignaban a la casa Baring 1.000 quintales de mercurio para que procediesen a su venta sin condiciones ${ }^{57}$. En mayo se definían, por fin, unas bases para la venta en comisión aceptadas por ambas partes: durante el tiempo de duración del contrato se entregaría a los Baring en exclusiva toda la producción para que éstos, o sus agentes, la vendieran en las condiciones más ventajosas. La comisión sería de un 3 por 100 , otro tanto en caso de que las ventas se realizasen fuera de Inglaterra. A medida que fuesen recibiendo el conocimiento de embarque de cada partida, los Baring irían adelantando 100.000 libras esterlinas a cuenta del producto de la venta del azogue, valorando cada quintal (de 104 libras) en 10 esterlinas. El interés sobre el anticipo sería del 6 por 100 , más una comisión bancaria de un 1 por $100^{58}$.

Preocupaba a los Baring la posibilidad de entrar en competencia con los Rothschild, que disponían de 35.000 quintales en Europa, sin sacrificar excesivamente los precios. La alternativa, esperar seis u ocho meses a que el control del mercado pasase definitivamente a sus manos, disminuía evidentemente la rentabilidad de la inversión y aumentaba los riesgos. Para evitar futuras complicaciones con sus vecinos de la City, los Baring incorporaron a las bases del convenio una cláusula importante: se les autorizaría a emprender negociaciones con los Rothschild para garantizarse una parte del mercado y negociar el mantenimiento de los precios.

El 6 de mayo de 1848 las condiciones de los Baring eran remitidas a Madrid. Debían ser aceptadas por el Banco y ratificadas en Londres a lo largo del mes. Pero el día 10 se producía una inesperada rescisión del contrato con el Fomento que sorprendía a Falconet en París. Ante las dificultades experimentadas por el Banco y las estrecheces monetarias de la plaza, el Ejecutivo se había visto obligado a aceptar una novación del contrato solicitada por aquél en noviembre de 1847: el anticipo se limitaría a los 30 millones ya entregados ${ }^{59}$. Pero el alivio resultó insuficiente, y para evitar el recurso a los dividendos

56 La correspondencia de BB a Antonio Jordá en BBA, LB, núm. 18, 26 de abril de 1848, pp. 19 y ss.

57 Un testigo de esta operación puede encontrarse en BBA, Spanish Ledgers, núm. 18.336/2.

$58 \mathrm{RAL}, \mathrm{XI} / 109 / 66$, Condiciones propuestas por los Sres. Baring de Londres, 6 de mayo de 1848, y BBA, LB, núm. 18, pp. 48 y ss.

s9 DSCD, núm. 44, 22 de enero de 1850, p. 1069, discurso de Bertrán de Lis. Antes de verificarse dicha alteración, el conde de la Romera, entonces titular de Hacienda, creyó que debía proponerse el negocio a la casa que había entrado en licitación con el Banco. Rechazado por ésta, se produjo la novación. 
pasivos que hubiera precipitado el valor de las acciones ya depreciadas, a fines de diciembre el Fomento se fusionó con otras dos sociedades dedicadas a realizar negocios similares, ambas en manos del mismo grupo de capitalistas: el Banco Español de Ultramar y Empresa de Correos Marítimos por una parte, la Probidad por otra. De dicha fusión nacía el Banco de Fomento y Ultramar ${ }^{60}$.

Vinieron después los acontecimientos políticos de febrero de 1848 en Francia y el resto de Europa, trastornándose la situación del comercio de Madrid como se había trastornado el del continente. Entonces el Banco solicitó una segunda novación, pero el nuevo titular de Hacienda, Bertrán de Lis, optó por rescindir el contrato el 10 de mayo de $1848^{61}$. Poco después daba cuentas de su actuación en las Cortes: la Hacienda necesitaba recursos, y él procuraba obtenerlos haciendo uso del crédito. El ministro intentaba reunir todos los valores posibles «no para venderlos, sino para hipotecarlos a fin de sacar al Tesoro de la situación desfavorable en que se encontraba. Por eso, señores, tenía yo interés en hacerme con los azogues, porque preveía que el Banco de Fomento no podía realizar su contrata, estaba embarazando al gobierno y le privaba de una de las mercancías más pingües para el comercio extranjero» ${ }^{62}$. La aventura del azogue había supuesto para el Fomento una pérdida de 1.843.053 reales $^{63}$.

A partir de la rescisión, los acontecimientos se sucedieron con rapidez. Era el Gobierno el que tomaba el lugar del contratista y tenía que resolver de inmediato el problema de la venta de las existencias retiradas al Fomento. El mismo Real Decreto que anunciaba la rescisión entregaba al Nuevo Banco Es-

60 Sobre la fusión véase la Circular del Banco de Fomento, 26 de diciembre de 1847, en BBA, HC4.8.7, y TEDDE, P.: El Banco..., pp. 136 y 220.

61 Aunque Tortella, G. sostiene que el Banco se liquidó en 1848, Los orígenes..., p. 36, parece que pudo capear la crisis y prolongó su vida hasta 1856. Banco de Fomento y Ultramar. Memoria que la Junta liquidadora presenta a la general de accionistas sobre la rescisión del contrato de Correos y Transportes Marítimos, Madrid, 1856. En septiembre de 1849, su director se dirigía al ministro de Ultramar solicitando la devolución del derecho adeudado por las cantidades de mercurio que habían importado en Cuba y tenían almacenadas en La Habana por la proximidad de aquél puerto a los centros de consumo en el continente, AHN, Ultramar, Hacienda, leg. 666/1, exp. 5. Sobre las liquidación del empréstito de 200 millones del anticipo para caminos, ARTOLA, M.: Los ferrocarriles..., vol. I, pp. 20-21.

62 Posteriormente se defendía de los ataques que se le habían dirigido por no haber exigido indemnización al Banco. Si el Gobierno se hubiese empeñado en exigir lo convenido -indicaba- la sociedad hubiera quebrado con los efectos que hubiera producido la desaparición de una compañía que había llegado a ser importante. En Francia, por ejemplo, hasta la casa Rothschild, que había pedido una modificación de un contrato de anticipo al Gobierno francés, lo había obtenido. En España los bancos y las casas de comercio estaban dando también muestras de templanza. Por otra pare, el gobierno era el que había tomado la iniciativa de la rescisión. En tercer lugar, había otra cuestión importante: si el Banco no había cumplido en el asunto de los azogues, era el Estado el que estaba en deuda con él por la cuestión del anticipo de 200 millones del empréstito de los caminos, DSCD, núm. 44, 22 de enero de 1850, p. 1069.

63 Memoria del Banco de Fomento y Ultramar..., p. 22. 
pañol de San Fernando ${ }^{64}$ la totalidad de las existencias (35.000 quintales) para que se encargase de venderlos por cuenta de la Hacienda sin comisión, sirviendo el azogue para reforzar la garantía de sus anticipos al Tesoro ${ }^{65}$.

Las circunstancias en las que el Banco se ocupó del azogue no resultan claras. Sabemos que uno de sus accionistas partió hacia Londres para intentar negociar con la casa Murrieta. En cualquier caso, parece que el San Fernando estuvo poco tiempo encargado de la venta. Efectivamente, la situación tomó un giro completamente inesperado cuando en nombre de los Baring, el 20 de mayo, Enrique O'Shea ofrecía al Gobierno encargarse de la venta del azogue en comisión en los términos que acababan de ser propuestos al Fomento. El Ejecutivo retiró entonces al San Fernando su encargo, iniciando de inmediato negociaciones con los Baring ${ }^{66}$. Dado que apenas habían transcurrido diez días desde que el San Fernando se encargó de la venta del azogue y el momento en que dicho encargo fue retirado, no parece posible que fuera relevado de sus obligaciones por haber fracasado en el cometido de dar salida al mercurio, como se ha sugerido ${ }^{67}$.

El 30 de mayo Thomas Baring escribía a Falconet a París. Le anunciaba que el Gobierno estaba dispuesto a confiarles 35.000 quintales y le autorizaba para firmar un convenio, remitiéndole los poderes necesarios para ello. Los Baring creían que era indispensable concertar paralelamente acuerdos para garantizar la estabilidad del mercado. A su juicio era preciso entenderse con los Rothschild o bien lograr que quienes compartían con ellos la contrata - entre otros el marqués de Grimaldi, que disponía de 10.000 de las 20.000 botellas almacenadas en Europa - les entregasen su mercurio en comisión a cambio de un anticipo ${ }^{68}$.

El negocio estaba a punto de caer en manos de los Baring, cuando una hábil maniobra de Weisweiller lograba que la firma del contrato con el Gobierno, ya ultimado, fuese aplazada. La contrariedad que las negociaciones entre Baring y el Ejecutivo produjeron en los Rothschild quedaba patente en la carta que Weisweiller dirigía a Mon el 22 de mayo, dos días después de la propuesta de los Baring. Era cierto - admitía el banquero- que antes de rescindir el contrato con el Fomento, los Rothschild habían rechazado una propuesta del ministro de Estado, el duque de Sotomayor, para que adquiriesen el mercurio a 86 pesos el quintal, el mismo al que se le había vendido al Fomento (véase más arriba nota 59). Ello no quería decir, no obstante, que no estuviesen dispuestos a hacerse cargo de su venta en comisión. No pedía que se les diera pre-

${ }_{64}^{64}$ Surgido de la fusión con el Banco de Isabel II en febrero de 1847. Para un estudio de esta entidad, TEDDE, P.: El Banco...,

6s Colección Legislativa de España, tomo XLIV, 1848, pp. 31-32.

${ }_{66}$ BBA, HC4.8.9, M. de la Sierra a BB, 13 y 28 de junio de 1848 . Tedde, P.: El Banco..., p. 221, recuerda que al San Fernando no le fue fácil vender el metal y que hasta agosto no logró dar salida a los primeros 500 quintales. Probablemente se trata del mercurio propio que le había sido entregado por el Fomento, toda vez que le fue retirado el encargo de venta en mayo.

67 Martín Martín, V.: Los Rothschild..., p. 234.

68 BBA, LB, núm. 18, BB a Falconet, 30 de mayo de 1848. 
ferencia; deseaba únicamente que el Gobierno enviase un representante a Londres para escuchar las ofertas de ambas casas ${ }^{69}$. Alejandro Mon, no tuvo más remedio que acceder. El Gobierno atravesaba en aquel momento intensas dificultades que habían conducido a un elevado endeudamiento con el San Fernando, la presión del ejecutivo había situado al Banco en una posición difícil. Para procurarse liquidez, el establecimiento había comenzado a enajenar en Londres títulos de la deuda del 3 por 100 obtenidos en garantía de sus anticipos del Tesoro. En esta operación necesitaba contar con el apoyo de los Rothschild ${ }^{70}$.

\section{EL DESARROLLO DE LAS NEGOCIACIONES EN LONDRES Y LOS PRÉSTAMOS CON GARANTÍA DE MERCURIO}

Por Real. Decreto de 26 de mayo de 1848, inmediatamente después de conocer la propuesta de Weisweiller, Bertrán de Lis encargaba al subsecretario de Hacienda, Manuel de la Sierra y Moya, que se ocupase de negociar la venta del azogue. Debía trasladarse a Londres, el mercado más importante; entrevistarse directamente con Rothschild y Baring y decidir, en fin, sobre la venta en los términos más beneficiosos para el Tesoro. Años más tarde el ministro daba cuenta de la gestión de su subsecretario en las Cortes: «Había allí una casa que ahora había hecho una proposición sobre azogues, y por consiguiente podía sacarse más beneficio por la competencia entre esta casa y la que siempre había hecho este negocio» ${ }^{11}$. Evidentemente, el Gobierno quería aprovechar el enfrentamiento que parecía dibujarse entre las dos mayores casas de banca europeas por la comercialización del mercurio español.

Tras su llegada a la capital británica, el día 13 de junio Sierra se dirigía a Bishops Gate y a St. Swithin's Lane, sedes de Baring Brothers y de N.M. Rothschild \& Sons en la City. Frente a la venta en comisión propuesta por los Baring, insistía en que el Gobierno prefería negociar la venta definitiva del mercurio, como se había realizado desde 1830 , siempre que se asentase sobre un precio adecuado y previo anticipo de 600.000 libras. Entre las condiciones de la contrata, debía incluirse la entrega inmediata de las cantidades necesarias para pagar puntualmente el semestre del 3 por $100^{72}$ que vencía a fin de mes, si la falta de papel sobre Londres, aguda entonces en Madrid, impedía que las remesas llegasen a tiempo. Como garantía se ofrecía, además del azogue, la entrega de una serie de libranzas sobre las cajas de La Habana con vencimientos lo lago de 1848.

69 RAL, XI/109/66, Weisweiller a Mon, 22 de mayo de 1848.

70. TEDDE, P.: El Banco..., p. 199.

71 DSCD, núm. 44, 22 de enero de 1850.

72 Este título, creado en virtud del arreglo de la deuda de 1831, era el único que venía cobrando sus intereses regularmente, lo cual determinaba una buena marcha de sus cotizaciones. El resto de las deudas había quedado desatendido desde 1836, ArTOl.A, M.: La Hacienda..., pp. 266 y 268. 
Conforme a estas bases ambas casas debían formalizar su proposición y designar un representante para tratar con Sierra ${ }^{73}$. No era, seguramente, el momento más adecuado para negociar: a la crisis del mercado del mercurio ocasionada por la invasión americana de México, se añadía la incertidumbre política y comercial que sacudía a Europa, y ambas casas rechazaron las bases ${ }^{74}$. Los Baring aceptaban, no obstante, ocuparse del pago del dividendo: adelantarían las cantidades precisas, nunca más de 30.000 libras, a un 5 por 100 de interés, y recibirían como garantía mercurio valorado en 50 pesos el quintal por una cantidad equivalente a la anticipada. Los adelantos debían reintegrarse en el plazo de un mes, de lo contrario quedarían autorizados para vender el mercurio al precio más ventajoso del mercado ${ }^{75}$.

A fines de junio Sierra remitía a ambos banqueros y a Juan Grimaldi, que desde París parecía interesarse por el negocio, una nueva propuesta: la venta definitiva de 35.000 quintales depositados con el Banco de San Fernando al precio de 75 pesos fuertes, y un anticipo de 200.000 libras, la mitad a la firma del contado y el resto a quince y treinta días. Debían contestar antes del 1 de julio. Pese a sus firmes deseos de establecer relaciones con el Gobierno, los Baring rechazaron nuevamente la propuesta ${ }^{76}$. En cuanto a los Rothschild, se comprometían a adquirir los 35.000 quintales a 60 pesos y ofrecían un adelanto de 150.000 libras, siempre y cuando se les permitiera comprar al mismo precio la producción de los cuatro años siguientes si les conviniera ${ }^{77}$. Las condiciones resultaban inaceptables.

A falta de comprador que tomase en firme el azogue disponible, no iba a quedar otra solución que la venta parcial o en comisión. Sierra decidió volver a Madrid y dejar que fuera el Gobierno el que tomara la decisión ${ }^{78}$. Antes de iniciar su viaje de regreso preparó un borrador de contrato sobre la base del propuesto por los Baring y lo remitía a ambas casas. Así se ahorraría tiempo en caso de que el ministro de Hacienda admitiera la venta en comisión. Al llegar a Madrid traía consigo una proposición de los Baring fechada el día 15 de julio 79. El Gobierno les entregaría para que vendiesen durante los años 1848 y 1849 los 35.000 quintales por cuenta del Tesoro. Fijaría un mínimo, que no podría superar las once libras el quintal, por debajo del cual no se podría vender sin su

73 BBA, HC4.8.6, Sierra a Baring y Rothschild, 13 de junio de 1848.

74 BBA, HC4.8.6, Sierra a Rothschild Frères, 28 de junio de 1848. También pueden encontrarse referencias a este viaje de Sierra en DSCD, núm. 43, 21 de enero de 1850, discurso de Bermúdez de Castro, pp. 1050 y ss. y de Bertrán de Lis, núm. 44, 22 de enero de 1850, p. 1072.

75 BBA, LB, núm. 18, p. 115, 15 de junio de 1848 y DSCD, núm. 44, 22 de enero de 1850 , p. 1072.

76 BBA, LB, núm. 18, p. 116, BB a Sierra, 30 de junio de 1848.

${ }_{77}$ Citado en la carta de Sierra a Rothschild Frères, 28 de junio de 1848.

78 BBA, HC4.8.10, marqués de Fuentes de Duero a BB, 30 de diciembre de 1848. En ese momento tenía una cuenta abierta con un saldo de 20.000 libras.

$79 \mathrm{BBA}, \mathrm{LB}$, núm, 18, pp. 179 y ss., 15 de julio de 1848 . 
consentimiento. Se les abonaría un 3 por 100 de comisión en las ventas en Gran Bretaña y otros países. Los Baring anticiparían 150.000 libras a un 6 por 100 de interés contra entrega de mercurio valorado al precio mencionado.

La necesidad de asegurar la existencia de un monopolio que garantizase el mantenimiento'de los precios en el mercado mundial no se les escapaba. De esta preocupación nacían una serie de cláusulas: se les autorizaba, en primer lugar, a llegar a un acuerdo con los Rothschild encaminado al mantenimiento de los precios y al logro de una justa participación de ambos en las ventas. El Gobierno se comprometía, además, a entregarles todo el mercurio que tenía depositado en Londres, de modo que en aquella plaza no hubiese más metal que el que hubiera en manos de Baring o Rothschild. El Ejecutivo se comprometía, igualmente, a hacer arreglos con el San Fernando y el Fomento para evitar que el mercurio que tuvieran fuese comprado o vendido en competencia con el consignado en el contrato. Finalmente, no podrían realizarse nuevos contratos sin que previamente la Hacienda hubiese liquidado sus cuentas con los Baring.

Aunque el plazo dado para que el Gobierno aprobase el contrato era de un mes, hasta noviembre de 1848 Mon, sucesor de Bertrán de Lis en Hacienda, no se ocupó del asunto. El día 9 invitaba a los Baring a nombrar un comisionado para concluir definitivamente el asunto y les proponía participar en la negociación de 26 millones de reales en libranzas sobre La Habana. Pero las condiciones políticas y financieras en Europa habían ido empeorado, en tanto que el mercado norteamericano ofrecía grandes oportunidades a la inversión de capitales. De modo que los Baring declinaron hacerse cargo del mercurio en los términos que habían propuestos en junio ${ }^{80}$.

El día 8 de diciembre Mon tomaba, por fin, una decisión. Acababa de rescindir el contrato de Tesorería con el San Fernando que atravesaba, como vimos, una situación delicada. El Banco se había estado ocupando de anticipar las cantidades necesarias para el pago del semestre de la deuda ${ }^{81}$. Sin poder contar con él por más tiempo, era preciso garantizar el concurso de los banqueros. Se reunió con Weisweiller y con O'Shea y les anunció que estaba dispuesto a aceptar un empréstito de ambas casas por separado y en partes iguales. Cada una adelantaría 50.000 libras, que se pondrían a disposición de Joaquín Scheignagel, el presidente de la Comisión Española de Hacienda en Londres, a partir del 1 de enero de 1849. Los adelantos devengarían un 6 por 100 de interés y un 1 por 100 de comisión bancaria. Ambas casas recibirían en garantía de sus respectivos anticipos 5.000,25 quintales de mercurio. El 1 de abril debían saldarse los anticipos e intereses, salvo que fuera consentida la prórroga. En caso contrario, los banqueros podrían vender el mercurio al mejor precio posible para reintegrarse de la totalidad del adelanto, cargando un 3 por 100 de comisión y corretaje. Durante el tiempo que durase el contrato, no podría venderse ni consignarse mercurio a ningún otro establecimiento.

80 BBA, LB, núm. 18 , p. 397 , BB a Mon.

81 TEDDE, P.: El Banco..., pp. 164 y ss.

Hispania, LXIII/1, núm. 213 (2003) 255-294 
Tales eran las condiciones del contrato firmado por separado con cada una de las casas y aprobado por dos Reales Órdenes de 10 de diciembre de 1848. Eran los primeros de una larga serie de contratos de anticipo con garantía de mercurios ${ }^{82}$. Se trataba de un expediente temporal que proporcionaría los recursos para el pago del dividendo que vencía en enero. Así se superaba una urgencia financiera del momento, pero no se resolvía el problema básico de la enajenación del mercurio. Insistimos en que estos contratos implicaban únicamente adelantos con garantía de mercurio y no contratos de venta en comisión. Tras la firma del contrato, Enrique O'Shea escribía satisfecho a los Baring: aquello era el preludio que podía conducir a la obtención de la comisión para la venta del mercurio, o al menos de la mitad.

No había concluido el mes de diciembre, cuando Mon se dirigía nuevamente a ambos banqueros pidiendo otro anticipo. Conforme al artículo octavo del convenio de 9 de diciembre, de requerir el Gobierno nuevos adelantos sobre azogue, tendrían preferencia los dos contratistas en iguales condiciones. El 27 de diciembre se firmaba un convenio con Weisweiller. Los Rothschild se comprometían a adelantar 12.000 libras, recibiendo a cambio 1.210 quintales de mercurio. O'Shea no firmó ningún contrato en ese momento, seguramente porque carecía de autorización ${ }^{83}$. Cuando en enero de 1849 se realizaban nuevos anticipos, los Rothschild sólo adelantaban 7.997 libras, en tanto que los Baring entregaban $20.000^{84}$.

A principios de febrero de 1849 Mon pedía otro anticipo. Se llegaba a una nueva operación de 20.000 libras $^{85}$. Weisweiller se había ofrecido a hacerse cargo de su totalidad, pero Mon aseguraba a O'Shea que no aceptaría sin antes haber hecho también a los Baring la oferta. Mostraba igualmente deseos de que éstos actuasen como agentes en el arreglo de la deuda que proyectaba. Les proponía, además, que adquiriesen las libranzas sobre Manila que tenía intención de emitir.

En marzo cada casa volvía a adelantar cerca de 10.000 libras $^{86}$. A fines de ese mes habían anticipado 100.000 libras cada una. Poco después Mon se veía

\footnotetext{
82 Martín Martín, V.: Los Rotbschild..., pp. 236 y 237 menciona este contrato firmado por Sierra en su calidad de subsecretario. Una copia en BBA, junto a la carta de la Dirección General del Tesoro a la casa Murrieta y Cía. de Londres, disponiendo la entrega de 5.000,25 quintales en el momento en que los Baring se presentasen confirmando la aceptación de la carta de pago que por importe de 50.000 libras había entregado su representante en Madrid, y que se remitía a la orden del presidente de la Comisión de Hacienda.

83 BBA, LB, núm. 18, p. 22, BB a O'Shea, 22 de diciembre de 1848.

${ }_{84}$ El contrato firmado por Sierra el 9 de enero de 1849 en, AHN, Hacienda, Serie General, libro 10.986 , p. 183 .

8s BBA, HC4.8.6, O'Shea a BB, 4 de febrero de 1849.

86 Las cantidades entregadas según Martín Martín no coinciden con las mencionadas en la correspondencia entre Enrique O'Shea y Baring Brothers, que incluye relación detallada de todos los contratos. Hay que señalar también que conforme a las condiciones del primer contrato, ambas casas se comprometían a adelantar en iguales condiciones y cantidades, lo cual hace difícilmente
} 
obligado a solicitar la prórroga del primer anticipo que vencía el 1 de abrili ${ }^{87}$. Iría haciendo lo mismo con los restantes.

\section{CUADRO II}

ANTICIPOS REALIZADOS POR BARING Y ROTHSCHILD A LA HACIENDA ENTRE 1848 Y 1850

\begin{tabular}{llcr}
\hline FECHA & $\begin{array}{c}\text { CONTRATO DEL } \\
\text { PRESTAMISTA }\end{array}$ & $\begin{array}{c}\text { CANTIDAD } \\
\text { (esterlinas) }\end{array}$ & $\begin{array}{r}\text { MERCURIO } \\
\text { (quintales) }\end{array}$ \\
\hline 9 XII 1848 & BARING & 50.000 & 5.000 \\
9 XII 1848 & ROTHSCHILD & 50.000 & 5.000 \\
27 XII 1848 & ROTHSCHILD & 12.000 & 1.210 \\
9 I 1849 & BARING & 20.025 & 2.000 \\
9 I 1849 & ROTHSCHILD & 7.997 & 799 \\
7 II 1849 & BARING & 5.000 & 501 \\
7 II 1849 & ROTHCHIL & 20.319 & 2.301 \\
23 II 1849 & BARING & 15.31988 & 1.530 \\
8 III 1849 & ROTHCHILD & 9.677 & 969 \\
22 III 1849 & BARING & 9.677 & 969 \\
20 VII 1849 & BARING & 50.000 & 6.000 \\
20 VII 1849 & ROTHCHILD & 50.000 & 6.000 \\
22 VIII 1849 & BARING & 7.500 & 792 \\
22 VIII 1849 & ROTHCHILD & 7.500 & 792 \\
17 XII 1849 & BARING & 50.000 & 6.000 \\
17 XII 1849 & ROTHCHILD & 50.000 & 6.000 \\
TOTAL & & 414.994 & 44.896 \\
\hline
\end{tabular}

FUENTE: Formado a partir de los diversos contratos localizados en BBA, cotejados con la documentación procedente del AHN, Hacienda, Serie General, libro 10.986. Las cifras difieren de las proporcionadas por Martín Martín porque, como éste indica, no contabilizó la totalidad de los contratos, op. cit., pp. 240-241.

comprensibles algunas de las cifras proporcionadas por MARTín MARTín, Los Rotbschild..., p. 240. Finalmente, debe señalarse que los contratos de enero de 1849 son contratos idénticos a los anteriores, contratos de préstamo con garantía de mercurios. No se trata de venta en firme del azogue entregado como parece sugerir en la p. 241.

87 BBA, HC4.8.6, BB a Mon, 17 de marzo de 1849 , citado en la carta de O'Shea de 18 de abril, y AHN, Hacienda, Serie General, libro 10.986, p. 403, Real Orden de 9 de marzo de 1849.

${ }_{88}$ AHN, Hacienda, Serie General, libro 10.986, p. 275. La Real Orden de 23 de febrero dispuso que con objeto de que los Baring quedasen en iguales condiciones que los Rothschild, el convenio celebrado el día 7 para el anticipo de 5.000 libras se ampliase hasta 20.319. La Dirección General del Tesoro debía aceptar de O'Shea letras contra Baring por valor de 15.319 libras y entregar 1.530 quintales en las atarazanas de Sevilla.

Hispania, LXIII/1, núm. 213 (2003) 255-294 


\section{DEL FRACASO DE LA SUBASTA A LA VENTA EN COMISIÓN}

En la primavera de 1849 los Baring parecían renovar su interés por penetrar el ámbito de las finanzas españolas y pensaban en otras operaciones con el Tesoro que pudieran resultar beneficiosas. No descartaban la posibilidad de involucrarse también en el anticipo con garantía de libranzas sobre las cajas de Filipinas propuesto por Mon. Como el negocio les parecía interesante, en el mes de marzo se dirigían a O'Shea aceptando participar en una operación en libranzas sobre Manila por importe de medio millón de pesos al 70 por 100 , tomando de inmediato las 250.000 y aplazando el resto un mes, para poder hacer el pago con las primeras 50.000 libras adelantadas contra mercurios que vencían en abril ${ }^{89}$. Deseaban saber, no obstante, qué proyectos albergaba Mon respecto al azogue porque no querían correr el riesgo de tenerse que hacer cargo del mismo una vez que hubiesen hecho una importante inversión en libranzas. En ese momento tenían anticipadas ya 100.000 libras. Habían entrado en el juego de los adelantos para estar en posición ventajosa, o al menos en condiciones de igualdad con los Rothschild, en el momento en que se decidiese la venta en comisión del mercurio, y les exasperaba la lentitud de Mon, cuya capacidad de relegar cualquier asunto era, en palabras de O'Shea, proverbial. Lo cierto es que los contratos de anticipo de fondos con hipoteca de mercurios permitieron a Mon ir haciendo frente al pago de los cupones de la deuda exterior.

Los sucesivos ministros venían estudiando la mejor manera de disponer del metal, incluso llegaron a valor la posibilidad de que la Hacienda se ocupara directamente de su comercialización como antes de 1830. Cancelada la contrata del Fomento, Bertrán de Lis despachó al subsecretario hacia Londres, pero al mismo tiempo se dirigía al conde de Villanueva, superintendente de Hacienda en La Habana, para que desde aquel enclave, próximo al principal mercado consumidor, evaluase las circunstancias del mercado ${ }^{90}$. En su respuesta del 8 de agosto de 1848, Martínez de Pinillos reflexionaba sobre las ventajas de que el Gobierno remitiese el metal a México por su cuenta. Si lograba que se adquiriera el mercurio de primera mano, más barato que el proporcionado por el monopolio de la contrata, el consumo - creía Villanueva - crecería. Poco después una casa de Veracruz se ofreció a recibir el mercurio en aquel puerto y a distribuirlo al menudeo en el interior de la república en condiciones que fueron rechazadas ${ }^{91}$.

Ante la situación crítica del mercado mexicano y la drástica caída de los precios, considerando inaceptables las propuestas, el Gobierno decidió seguir hipotecando el producto a las casas de Londres en tanto intentaba nuevamente

\footnotetext{
89 BBA, LB, núm.19, p. 175, 10 de marzo de 1849.

90 DSCD, núm. 42, 19 de enero de 1850 , p. 1032, discurso de Mon.

91 Tomarían los azogues a 7 por 100 comisión y anticiparían el 70 por 100 del precio que tuvieran en México. DSCD, núm. 43, 21 de enero de 1850, p. 1058, discurso de Mon. Hubo también una oferta del Tribunal de Minería para adquirir a 62 pesos los azogues puestos en México, situándolos el Gobierno en los depósitos de Tampico y Veracruz, Ibíd., p. 1054.
} 
la venta en firme mediante licitación pública. La Gaceta del día 12 de abril de 1849 sentaba las bases de una nueva subasta que se celebraría en mayo. Los contratistas recibirían los 20.000 quintales que el Gobierno tenía en Londres depositados con Rothschild y Baring (Cuadro 2), y los que se produjeran durante cuatro años a partir del 12 de mayo. El precio sería de 86 pesos $(1.730$ reales) el quintal, el mismo al que lo había tomado el Banco del Fomento. Conocida la intención de celebrar una subasta, el 2 de abril los Baring instruían a su agente para que suspendiera la negociación de las letras sobre Manila ${ }^{92}$. La licitación tuvo lugar el 11. de mayo. Weisweiller dejó sobre la mesa un sobre cerrado que no contenía proposición alguna, sino una carta cuyo contenido fue hecho público en el acto: dado que el Gobierno no fijaba la cantidad que entregaría anualmente y mientras este punto quedase abierto - indicaba-, los Rothschild se abstenían de hacer cualquier oferta; sin embargo — proseguía-, estaban dispuestos a dar todo tipo de facilidades para la venta en comisión ${ }^{93}$.

El resultado no sorprendió a nadie. El mínimo señalado por el Gobierno resultaba excesivamente elevado. Era obvio que ante las nuevas condiciones del mercado no habría establecimiento dispuesto a tomar en firme una cantidad indefinida de mercurio por espacio de cuatro años, toda vez que los precios parecían estabilizarse en torno a 70 pesos por quintal ${ }^{94}$. Sabiendo esto, Mon no buscaba sino quedar a cubierto de los ataques de la oposición si finalmente se veía obligado a vender a los precios de mercado95. La incertidumbre que arrojaba el descubrimiento de las minas de Nuevo Almadén en las proximidades de la ciudad de San Francisco ${ }^{96}$, cuyos potenciales efectos sobre los precios en el mercado internacional aún no era posible sopesar con seguridad, demostraba que, al menos temporalmente, era imposible que el Tesoro siguiera apegado a las fórmulas que venían observándose desde 1830 para la enajenación de los azogues. Se imponía la venta en comisión. En cualquier caso, Mon quedaba en una compleja y difícil situación: el Gobierno había obtenido adelantos de las dos casas londinenses por importe de 250.000 libras, y éstas tenían en depósito, sin darles salida, más de 20.000 quintales, aproximadamente la producción de un año; por otra parte, se acercaba el 1 de julio y era preciso preparar fondos para

92 BBA, HC4.8.6, 9 de abril de 1849 , O'Shea a BB.

93 Ibíd., 11 de mayo de 1849.

94 Martín Martín, V.: Los Rotbschild..., p. 227; BBA, LB, núm. 19, 19 de abril 1849, p. 233.

95 BBA, HC4.8.6, O'Shea a BB, 11 de mayo de 1849.

${ }_{96}$ Conocida su existencia desde hacía tiempo, Nuevo Almadén fue denunciado hacia 1843 . No había dado prácticamente resultados cuando la invasión americana obligó a sus propietarios a refugiarse en Tepic. En 1848 eran propietarios de las acciones la casa inglesa Balton Barron y Cía (seis y media), la francesa Yecker Torre y Cía de Mazatlán (tres y media). Las dos restantes pertenecían a Manuel Escandón y Antony Gibbs and Sons. Véase RAL, XI/38/77A, L. Davidson a N.M. Rothschild, 3 de diciembre de 1850 . A fines de 1852 Balton adquirió la parte de Yecker por 340.000 pesos. Su capital inicial de 500.000 pesos, a fines de 1858 se estimaba en algo más de 1.500 .000 . El azogue empezó a aparecer en los mercados de México a principios de 1850 . Sobre el origen de estas explotaciones puede consultarse SÁNCHEZ MOLERO, L.M.: Memoria..., pp. 11 y ss. 
el pago del cupón del 3 por 100 exterior, que desde el segundo semestre de 1848 se había satisfecho con los anticipos de ambas casas. No había pues más remedio que continuar por este camino y gestionar rápidamente un nuevo adelanto.

Desde principios de año los Baring habían insistido en que el Gobierno les autorizase para vender el mercurio depositado en sus manos. Así parecían aconsejarlo las noticias que recibían de México sobre los resultados previsibles de las minas de Nuevo Almadén, donde a la sazón se encontraban Edward Baring y el propio Falconet, que había sido enviado para negociar con el Gobierno mexicano un arreglo de la deuda en representación de los tenedores británicos. Mon se había opuesto sistemáticamente a la venta, seguramente esperando que una eventual recuperación de los precios permitiera enajenar en firme todo el mercurio. Esta política fue duramente censurada en las Cortes por Bermúdez de Castro, en cuya opinión evitar la venta del mercurio en Londres era un grave error. Desde la oposición aconsejaba al Ejecutivo que se adaptase a las nuevas circunstancias y vendiese ${ }^{97}$.

Sin autorización para vender - habían advertido en reiteradas ocasiones los Baring-, no estaban dispuestos a proseguir por el camino de los anticipos. No había pues más remedio que ceder y autorizar la venta. Tras meses de dilación, a raíz de los resultados de la subasta, Mon encargaba a Sierra que elaborase el borrador de una orden de ventas que con fecha de 5 de junio era enviado a ambas casas $^{98}$. Quedaban autorizadas para vender en comisión en cualquier mercado el mercurio que tenían depositado en virtud de los contratos celebrados desde fines de 1848 , siempre y cuando el precio de venta garantizase al Gobierno tres chelines, unos 69 pesos por libra inglesa.

La decisión ministerial contrarió visiblemente a Weisweiller. Los Rothschild disponían aún de un importante stock propio procedente de la contrata de 1843. Además, por mediación de su agente se habían ofrecido a hacerse cargo de las cantidades adeudadas a los Baring. Para los Rothschild se trataba, evidentemente, de asegurarse el monopolio del mercado, lo cual les había permitido controlar los precios en años anteriores. Pese a sus ofertas, Mon se negó reiteradamente a atender cualquier propuesta que implicara una ruptura de las conexiones que había logrado establecer con los Baring, cuyo apoyo financiero venía procurando, como vimos, desde 1844 .

\section{EL COMPLEJO PROBLEMA DEL PRECIO}

Dado que no se habían presentado licitadores a la subasta de mayo de 1849 -rezaba el preámbulo del decreto expedido por Mon el 20 de junio de

${ }_{97}$ Citado en BBA, HC4.8.6, O'Shea a BB, 4 de junio de 1853. Sobre este aspecto puede consultarse el voto particular de Bermúdez de Castro al dictamen de la comisión referente a la autorización para plantear los presupuestos, DSCD, núm. 43, 21 de enero de 1850, pp. 1051 y ss.

98 El documento en BBA, HC4.8.11.

Hispania, LXIII/1, núm. 213 (2003) 255-294 
184999 - se había resuelto autorizar a cada una de las casas a vender en comisión el mercurio que tenían en depósito, dando noticia al representante de España en Londres de las exportaciones que realizasen desde dicho puerto, y a los cónsules de las ventas que se efectuasen en otros lugares. Ambas casas obtendrían una comisión del 3 por 100 sobre la totalidad de las ventas hechas en Europa; otro tanto si éstas se realizaban fuera del continente. Los gastos de embarque, descarga y almacenaje correrían por cuenta del Gobierno, lo mismo que el de seguro, que sería realizado en Londres por cada una de las casas. Mon condicionaba la orden de ventas a la realización de un nuevo anticipo: cada casa adelantaría otras 50.000 libras a un 6 por 100 de interés y un 1 por 100 de comisión bancaria para el pago del dividendo de julio (Cuadro II). Dichas cantidades debían situarse en Londres el día 1. Recibirían a cambio 6.000 quintales de mercurio ${ }^{100}$. El precio mínimo de venta debía asegurar al Tesoro un neto de 3 chelines por libra inglesa.

Algunas de las condiciones establecidas para la venta no podían ser aceptadas por los Baring y dieron lugar a cierta tirantez en las relaciones. La cuestión más compleja era, evidentemente, la del precio de venta. Actuando como ministro, y sujeto a los ataques de una violenta oposición, Mon se veía obligado a tomar algunas precauciones: fijar un precio límite elevado por debajo del cual quedaba desautorizada toda venta, era para él prioritario. El precio mínimo establecido en la última subasta había sido de 86 pesos y Mon no creía posible reducirlo bruscamente a menos de 70 . Insistía en que el Banco de San Fernando acababa de fijar a Mildred Goyaneche \& Co. de Londres el límite de tres chelines dos peniques para una pequeña cantidad que les había consignado; él no podía aceptar uno inferior ${ }^{101}$.

Los Baring, por el contrario, exigían libertad para la venta. Sus argumentos eran también incuestionables; si el mínimo gubernamental no se podía obtener en el mercado, ellos no podrían realizar el mercurio que servía de garantía a sus anticipos. La situación se complicaba porque los Rothschild - que disponían de importante cantidad de azogue propio adquirido en subastas anteriores a precio más reducido- podrían ir vendiendo al precio de mercado ${ }^{102}$.

99 La Real Orden de 9 de junio en BBA, HC4.8.6.

100 BBA, HC4.8.6, O'Shea a BB, 16 de junio de 1849. «En este asunto hemos tenido discusión con el ministro porque quería entregarnos sólo 5.000, o lo que es lo mismo obtener un adelanto de 10 libras por quintal. Pero hemos conseguido una garantía adicional de 1.000 quintales».

${ }_{101}$ DSCD, núm. 43, 21 de enero de 1850, p. 1055, discurso de Bermudez de Castro.

102 BBA, HC4.8.6, O'Shea a BB, 25 de mayo de 1849. O'Shea había explicado a los Baring que una vez recibida la propuesta de orden de venta del Gobierno, debían elevar una representación a Mon anunciando que las ventas no podrían realizarse al precio establecido. Mon haría uso de dicha carta para responder a los ataques de la oposición, en caso de que el asunto llegase a las Cortes. Podría justificar así una reducción del precio de venta. Esta era la razón por la que O'Shea aconsejaba a Baring que aceptasen el precio. Estaba convencido de que el precio se reduciría después de la representación. 
Como respuesta a las quejas formuladas por los Baring sobre el precio de venta, el 7 de agosto se reunían Mon, Weisweiller y el director del Banco de San Fernando, que tenía todavía 3.000 quintales de los del Fomento: parte en manos de Mildred Goyaneche \& Co., sus agentes en Londres, el resto en Cá$\mathrm{diz}^{103}$. Después de prolongada discusión se comprometieron a no vender por debajo de tres chelines. Si alguno de los dos realizaba ventas a un precio inferir a dicho mínimo, los Baring podrían hacerlo al precio que fuesen capaces de obtener en el mercado. Con todo, el mínimo fijado era superior al que éstos estimaban posible: 2 chelines 9 peniques por libra, lo cual suponía para el Tesoro un neto de 2 chelines 6 peniques ${ }^{104}$. El tiempo vino a dar la razón a los Baring ya que, a los precios fijados, los banqueros no lograron dar salida a un solo quintal durante el tiempo en que estuvieron autorizados para vender en comisión ${ }^{105}$.

En esa situación sobrevenía la dimisión de Mon, sustituido por Bravo Murillo el día 19 de agosto de 1849. No habían pasado 24 horas cuando el nuevo ministro acudía a los representantes de ambas casas solicitando un anticipo sobre 1.584 quintales. Sin consentimiento de los Baring que habían advertido con claridad que no aceptarían nuevos adelantos mientras no se les autorizase a vender a 2 chelines 9 peniques, el 22 de agosto O'Shea se comprometía a realizar el nuevo adelanto (Cuadro II) ${ }^{106}$. Había decidido obrar así por varias razones: por una parte, se trataba de una cantidad muy reducida de mercurio; por otra, el ministro no podría reclamar nuevos anticipos hasta la campaña siguiente, ya que hasta entonces no dispondría de más metal. Además, O'Shea estaba convencido de que la resolución definitiva sobre el mercurio era inminente. Bravo Murillo no sólo había mandado a buscar a Sierra que se hallaba en Cádiz y a quien deseaba mantener a su lado como subsecretario, sino que, además, se había comprometido a plantear ante el Consejo de Ministros la cuestión que Mon había tenido pendiente durante semanas. Finalmente, O'Shea introdujo en el contrato del 22 de agosto una cláusula estipulando que en caso de que el Gobierno no aceptara el límite al que los Baring creían posible la venta, en el plazo de tres meses les sería devuelto el principal del último anticipo a un 6 por 100 de interés y 1 por 100 de comisión ${ }^{107}$.

103 Recuérdese que el 20 de julio de 1848 el Banco había dispuesto de los 4.760 quintales hipotecados por el Fomento a cambio de un anticipo, Memoria del Banco de Fomento ..., p. 21.

$104 \mathrm{La}$ reunión celebrada en el Ministerio sobre precios reseñada en la carta de O'Shea del 8 de agosto, BBA, HC4.8.6.

ios ZarraluQui, J.: Los almadenes..., p. 702. También puede verse SÁnChez Molero, L.M.: Memoria..., p. 49.

106 No sólo no se había autorizado la venta al mínimo exigido por Baring, sino que, además, por Real Orden de 14 de agosto, si bien se aceptaban las ventas que los Baring hubiesen podido realizar a tres chelines sin deducción de gastos segú se había acordado en la reunión del día 7, se les advertía que en el futuro se atuviesen al precio que garantizase tres chelines netos al Tesoro. La Real Orden en BBA, HC4.8.6.

107 BBA, HC4.8.6, copia del contrato de 22 de agosto de 1849 y carta de 24 de agosto.

Hispania, LXIII/1, núm. 213 (2003) 255-294 
En septiembre, un mes más tarde, Bravo Murillo se volvía a entrevistar con los agentes de los dos banqueros. Deseaba saber si alguno estaría dispuesta a comprar en firme la totalidad del mercurio que el otro tenía en su poder. Weisweiller aseguró que los Rothschild aceptarían si les convenía el precio de venta, siempre que el Gobierno se comprometiese a limitar la producción a 8.000 ó 10.000 quintales durante los tres años siguientes. Además tendrían la opción de tomar una cantidad mayor si llegado el momento lo creían oportuno.

Bravo Murillo - lo mismo que Mon - temía bajar los precios por miedo a la oposición. La opinión estaba acostumbrada a que se vendieran 20.000 quintales a más de 80 pesos el quintal y costaría que se aceptase uno bastante menor para cantidades muy inferiores. Después de plantear la cuestión a sus compañeros de gabinete, estaba convencido de que el único modo de cubrir su responsabilidad sería volver a la subasta ${ }^{108}$. El Consejo de Ministros del 9 de octubre de 1849 optó por sacar a pública licitación la venta del mercurio y la Gaceta del 30 publicó el pliego de condiciones: la subasta tendría lugar el 1 de diciembre, el contratista recibiría 12.000 quintales al año - que podrían elevarse a 20.000 si lo deseaba-, durante los cuatro de duración, que finalizarían en octubre de 1853. Se comprometía, además, a recibir en Londres al precio del remate los 33.585 quintales en poder de Baring y Rothschild (Cuadro II), excepto los que se hubiesen vendido hasta el momento de la subasta ${ }^{109}$. El Gobierno se obligaba pues a limitar la producción a 12.000 quintales al año, tal como había sugerido Weisweiller (Cuadro I).

\section{THOMAS BARING EN MADRID}

El 9 de noviembre de 1849 llegaba a Madrid Thomas Baring. Con breves interrupciones ocasionadas por los viajes realizados a Toledo, Aranjuez y a algún que otro lugar de nuestra geografía, permaneció allí hasta el 8 de diciembre. Iba dispuesto a estudiar la situación in situ y a tomar una decisión sobre la participación de su casa en la licitación. Su estancia en la capital de la monarquía transcurrió entre entrevistas con Narváez, Bravo Murillo, a su juicio un hombre trabajador, buen abogado, pero financiero de segunda fila, y Mon, a quien tenía por un hombre de gran inteligencia, pero sumamente indolente ${ }^{110}$.

Narváez y Bravo Murillo aseguraron a Thomas Baring reiteradamente que deseaban encargarles la venta en comisión de la totalidad del mercurio. En vísperas de la subasta, el ministro confesaba que no tenía esperanzas de alcanzar el precio mínimo que iba a exigir. En todo caso, el Gobierno no podía ba-

108 BBA, HC4.8.6, O'Shea a BB, 22 de septiembre de 1849.

109 El pliego completo en MARTín MARTín, V.: Los Rotbschild..., pp. 539 y ss.

110 Asiste también a alguna recepción de la reina madre y se entrevista con diversos banqueros y personajes madrileños. La correspondencia de Thomas Baring a sus socios durante su estancia en España se encuentra en BBA, HC1.20.4.

Hispania, LXIII/1, núm. 213 (2003) 255-294 
sarse en meras conjeturas sobre las tendencias del mercado y fijar un precio bajo como si los temores y suposiciones sobre la producción de California fuesen ya una realidad. Cuando el precio del quintal estaba en Londres a 75 pesos, no había justificación para realizar una contratación por cuatro años a un precio inferior. Convencido de que era muy probable que la subasta quedase desierta, deseaba saber si los Baring dispondrían de los recursos y estarían dispuestos a desembolsar las cantidades adelantadas por Rothschild. En términos más coloquiales, escribía Thomas Baring a sus socios de Londres, se había preguntado a O'Shea en una entrevista «por qué los Baring no les ayudaban a librarse de los judíos» ${ }^{111}$.

La transferencia de la totalidad de la venta a manos de Baring, mencionada incluso por el propio Narváez en alguna de sus entrevistas con O'Shea, resultaba, no obstante, bastante problemática tanto para el Gobierno, como para aquéllos $^{112}$. Por una parte, suscitaría contra el Ejecutivo la enemistad de la casa Rothschild, de la cual se temía que pudiese incluso llegar a invertir su capital en la explotación de las minas de California. Más temor producía la seguridad de que en el futuro impedirían que Weisweiller acudiese en su auxilio cuando a los Baring no les conviniese hacerlo. «El Gobierno español —escribía Jhosua Bates, uno de los socios de Baring Brothers \& Co. - no podrá salir adelante sin Rothschild, que a no ser que tenga el mercurio les abandonará» ${ }^{113}$. En cuanto a los Baring, pagar a Rothschild su crédito contra el Tesoro - unos quince millones de reales-y, a la vez, responsabilizarse del dividendo implicaba adelantos muy importantes. En cualquier caso, no estaban dispuestos a aceptar la venta en comisión con límite de precio. La posición de los Baring respecto a la subasta que se avecinaba era clara: por una parte, ante la incertidumbre del mercado no deseaban aventurar un elevado capital y consideraban excesivamente peligroso comprometerse a los mínimos que el Gobierno exigiría; por otra, no deseaban hacer pública una oferta muy baja que pudiera perjudicar la venta en comisión si el Ejecutivo se veía finalmente obligado a inclinarse por esa opción.

Durante los días previos a la subasta entablaron contactos con Weisweiller y discutieron sobre la posibilidad de llegar a un acuerdo ${ }^{114}$. Thomas Baring sugirió que ambas casas tomasen la contrata en las mismas condiciones mediante una licitación común. Esta combinación debía llevar aparejado el acuerdo para vender a un precio convenido ${ }^{115}$. Hasta la víspera de la licitación Tho-

III BBA, HC1.20.4, Thomas Baring a Jhosua Bates, 14 y 16 de noviembre de 1849.

$112 \mathrm{BBA}, \mathrm{HC} 1.20 .4,28$ de noviembre de 1849.

113 BBA, HC1.20.4, Jhosua Bates a Thomas Baring, 29 de noviembre de 1849.

114 BBA, HC1.20.4, Thomas Baring a John Baring, 16 de noviembre de 1849.

11s BBA, HC1.20.4, Thomas Baring a John Baring ,21 de noviembre. Pero los días transcurrieron sin que Weisweiller se pusiera en contacto con Baring para discutir sobre la licitación conjunta. Desconocemos las razones que impidieron el acercamiento. En su carta sin fecha (probablemente de octubre de 1849) a Meyer Rothschild, Lionel le preguntaba su opinión sobre un entendimiento con Baring. «Si yo estuviese en Madrid trataría de llegar a un arreglo, pero con Weisweiller es más difícil», era la respuesta, RAL, T8/229. 
mas Baring no había tomado todavía una decisión. Aguardaba una respuesta de Weisweiller y las noticias de sus socios de Londres. Lo cierto es que la correspondencia cruzada con sus socios aquellos días no denota gran entusiasmo. Discutían sobre el precio máximo que podrían arriesgar, se cuestionaban incluso las ventajas de reclamar al Gobierno la devolución de sus anticipos y abandonar totalmente el escenario. En el fondo, Thomas Baring opinaba que debían quedarse al margen de la contrata, pero deseaba que el ministro fijase un mínimo elevado que dejara abierta la posibilidad a la venta en comisión de la totalidad o parte del mercurio.

El 1 de diciembre tuvo lugar la licitación. Según el pliego de condiciones, el contratista recibiría 12.000 quintales anuales, producción máxima que el Gobierno se comprometía a extraer durante los dos años que habría de durar el contrato. Se haría cargo de los 33.585 quintales depositados en Londres con Baring y Rothschild, cuyo importe debía ser abonado en el plazo de un mes. Durante los dos años el Gobierno no podría vender mercurio, pero sí solicitar anticipos con su garantía ${ }^{116}$. Los Baring habían hecho el depósito requerido, lo mismo que Manzanedo, Casares y Weisweiller. Pero la única licitación que se presentó fue la de este último, que ofrecía 54,4 pesos por quintal, cantidad muy alejada de los 70 fijados por el Gobierno. Considerándose inaceptable la oferta de Weisweiller, la subasta se declaró desierta ${ }^{117}$.

Al día siguiente Thomas Baring se reunía con Bravo Murillo. Reconocía que la situación resultaba de todo punto insatisfactoria tanto para ellos como para el Ejecutivo. Deseaba que se autorizase la venta, ya que estaba convencido de que resultaría beneficiosa para el Gobierno. Àdvertía al ministro de Hacienda de los peligros de seguir aplazándola indefinidamente mientras se daba tiempo a que la producción de California llegara al mercado. Las informaciones que recibían de Falconet desde México reforzaban la idea de que Nuevo Almadén sería en breve un serio competidor. Los ensayos docimásticos que habían mandado realizar en Hatton Garden, en Londres, sobre las muestras de mineral de cinabrio que Edward Baring había recogido en California, arrojaban una riqueza del 56 por 100 de mercurio, amalgamado con aluminio, algo de sílice y óxido de hierro ${ }^{118}$. Los expertos calculaban que, dada la riqueza del mineral,

\footnotetext{
116 De hecho, poco después se entregaban al Banco de San Fernando 16.000 botellas como garantía de una operación en virtud de la cual el Tesoro emitía pagarés a la orden del Banco por valor de 80.000 libras. O'Shea suscribió tres millones de reales, BBA, HC4.8.6, O'Shea a BB, 7 de febrero de 1851.

117 Los Rothschild habían autorizado a Weisweiller a ofrecer 60 pesos en caso de que los Baring decidiesen concurrir; de lo contrario debían tratar de obtener el mercurio a 55, RAL, T8/188, 26 de noviembre de 1849 , Lionel de Rothschild a Mayer. Información sobre la subasta en la correspondencia de Thomas Baring de los días 1 y 3 de diciembre de 1849.

118 BBA, HC1.1.4, Assay Office, Hatton Garden. Nota del resultado de la prueba del cinabrio practicada sobre una muestra de Nueva California, 11 de diciembre de 1849.
} 
con la maquinaria y condiciones adecuadas el coste de producción podría reducirse a dos peniques por libra de mineral.

Bravo Murillo se había negado a subastar el mercurio a 54 pesos el quintal, y no estaba dispuesto a autorizar la venta en comisión si no era fijando un límite de precio. Se mostraba, no obstante, dispuesto a liquidar las existencias depositadas en Londres a un precio que se aproximase a su mínimo. Así pues, a raíz de aquella entrevista Thomas Baring elaboró una propuesta para hacerse cargo de dicha venta y abandonaba el país. Rechazada apenas una semana después, la Gaceta no tardaba en publicar un pliego de condiciones para una nueva subasta que tendría lugar el 5 de enero de $1850^{119}$.

Mientras perfilaba las condiciones de la licitación, Bravo Murillo recurría nuevamente a los representantes de los banqueros. El 17 de diciembre firmaba con ellos dos contratos para el anticipo de otras 50.000 libras para pagar el dividendo que vencía a fin de mes (Cuadro II). Como en esta ocasión se carecía de mercurio, el anticipo tuvo que hacerse contra una delegación de 6.000 quintales para cada casa sobre la cosecha del año entrante, que comenzaría a arribar a Sevilla en el mes de enero. Comisión e intereses serían similares a los previstos en contratos anteriores ${ }^{120}$. O'Shea firmó el contrato sin haber recibido autorización de Londres. Estaba convencido de que para sus representados era importante no retirarse en aquel momento dada la posición que habían alcanzado con el Gobierno y la inmediatez de la subasta. Durante aquellos días los Baring estudiaban la situación y llegaban a la conclusión de que no podrían ofrecer más de 55 pesos por quintal. Tenían presente que de obtener la contrata se tendrían que hacer cargo de los 33.585 quintales, competir con el resto de las existencias que los Rothschild aún conservaban y con la producción de los ricos yacimientos de Nuevo Almadén que comenzaba a presentarse en el mercado americano.

El 20 de diciembre Jhosua Bates escribía a Thomas Baring: «hasta hoy prácticamente nos hemos hecho cargo de la mitad del mercurio, en tanto que el ministro se las ha arreglado para dejar que los Rothschild vendan sus existencias. Weisweiller deberá estar satisfecho de que hayamos adelantado la mitad del dividendo. Estoy dispuesto a creer que hay una disposición para favorecer a

\footnotetext{
11 BBA, HC1.20.4, Thomas Baring a John Baring, 3 de diciembre de 1849.

120 En el caso de que en la subasta anunciada para el 5 de enero se realizase la venta de los azogues existentes en Londres en poder de las referidas casas, se entregaría a éstas el producto de la venta, saldando las cuentas abiertas por sus anteriores anticipos. Con el remanente se pagarían las cantidades objeto de la negociación. Respecto a la parte que quedase por reintegrar, se entregaría el azogue que correspondiese, pero no podría ser vendido por ninguna de las dos casas antes de que transcurriesen los dos años marcados en el pliego de condiciones. Durante el tiempo que pasase hasta el reintegro de todo o parte del anticipo, continuaría el abono del 6 por 100 de interés anual y 0,5 por 100 mensual, lo cual elevaba el interés anual al 12 por 100 de comisión de renovación. Si la subasta no daba resultado y el Gobierno no reintegraba en los plazos estipulados, las casas quedaban autorizadas a vender el azogue, objeto de la garantía, al límite de tres chelines fijado por el Gobierno o al precio de mercado; pero esta venta no se verificaría sino efectuada la de los 33.585 quintales en poder de las casas por anticipos anteriores.
} 
Rothschild y temo que aunque el ministro prefiera quizá entenderse con nosotros, no considere prudente romper con ellos si no es en una subasta abierta en la que gane la plica más alta. ¿Estamos preparados para hacer la licitación que nos daría el contrato? La operación envolvería más de 450.000 libras». La idea de que había una complacencia con Rothschild era compartida por la oposición que atacó duramente la gestión de los moderados. En el Congreso Bermúdez de Castro acusó a Mon de haber retardado la venta de azogues en Londres para dar lugar a que una casa extranjera vendiese sus existencias mientras que el precio caía en un 20 por $100^{121}$. El día 5 de enero la contrata fue adjudicada a los Rothschild a 70 pesos por quintal (1.400 reales) (Cuadro I). El Gobierno se comprometió a producir únicamente 12.000 quintales durante los dos años siguientes y a no vender en dicho plazo los 24.000 quintales producidos. Las condiciones suponían un enorme sacrificio para la Hacienda, ya que se renunciaba a producir 20.000 quintales $^{122}$.

Después de la subasta, O'Shea escribía a Thomas Baring: «Los Rothschild nos han vencido». O'Shea no había pujado a sabiendas de que el mínimo del Gobierno era muy superior a la cantidad finalmente autorizada por Baring: 60 pesos con 25 centavos el quintal ${ }^{123}$. Inmediatamente después de la licitación, el barón James de Rothschild escribía a sus socios de Londres aconsejándoles que adquirieran el mercurio que el San Fernando tenía allí depositado con Mildred Goyaneche $^{124}$. Debían pagar rápidamente a los Baring sus 157.000 libras y restablecer, cuanto antes, el monopolio que habían disfrutando desde 1835 .

A los Baring no les quedaba sino liquidar sus cuentas. Con todo, a juicio de O'Shea, no era conveniente que abandonaran el campo totalmente. Aconseja$\mathrm{ba}$, por tanto, que siguieran adelante con el último anticipo de 50.000 libras. Estaba seguro de que el ministro deseaba continuar entendiéndose con ellos en aquel o en cualquier otro asunto relacionado con el país ${ }^{125}$. Si no se había logrado establecer una relación más permanente - aseguraba-, al menos los Baring habían causado la mejor impresión como demostraban las intervenciones de Bertrán de Lis en las Cortes ${ }^{126}$.

\footnotetext{
121 DSCD, núm. 42, 19 de enero de 1850, p. 1032, citado en discurso de Mon.

122 Una discusión sobre los perjuicios de la contrata en DSCD, núm. 43, 21 de enero de 1850, p. 1055 .

123 BBA, LB, núm. 20 , p. 148, BB a O'Shea.

124 RAL, T8/234, 10 de enero de 1850.

125 BBA, HC4.8.6, O'Shea a BB, 5 de enero de 1850.

126 Efectivamente, el ministro de Hacienda había elogiado a los Baring por el apoyo prestado a Sierra: «Con una generosidad que no será nunca bastante alabada», habían asegurado a Sierra, preocupado porque los fondos para cubrir el dividendo no le llegaban, que podía anunciar su pago, respondiendo ellos de la cantidad que fuera necesaria. Esto le parecía al ministro más de agradecer por tratarse de una casa que jamás había entrado en negociaciones con el Gobierno español, DSCD, núm. 44, 22 de enero de 1850, pp. 1071-1072.
}

Hispania, LXIII/1, núm. 213 (2003) 255-294 


\section{BARING Y EL MERCURIO ESPAÑOL TRAS LA SUBASTA DE 1850}

Después de la subasta de 1850 los Baring continuaron estrechamente vinculados a los O'Shea con quienes realizaron ocasionales operaciones ${ }^{127}$. Además, no abandonaron enteramente el escenario de las finanzas públicas españolas. Las últimas 50.000 libras que se habían comprometido a adelantar el 17 de diciembre de 1849 , a su vencimiento, fueron reinvertidas una y otra vez en la adquisición de letras del Tesoro sobre las provincias con garantía de los pagarés de bienes nacionales. En junio de 1851 se hicieron cargo junto a O'Shea de un empréstito de 100.000 libras contra pagarés de los bienes de la Orden de San Juan de Jerusalén, cuyas propiedades se habían vendido pocos meses antes ${ }^{128}$. Enrique O'Shea había insistido en que los Baring tomasen el contrato a su nombre porque «me gustaría ver que se mantienen las conexiones entre el Gobierno y ustedes, entre otras razones por la posibilidad de que el mercurio sea vendido en comisión» ${ }^{129}$. En otras ocasiones no tuvieron tanto éxito. En 1852 Bravo Murillo decidía contratar por medio de licitación pública un anticipo de 360.000 libras, entregando a cambio títulos de la deuda interior al 3 por 100 . Junto a los Baring concurrieron a la subasta del 25 de junio los banqueros Foulds, Manzanedo, Tapia y Calderón, Salamanca, Sánchez de Toledo y, finalmente, Bayo que probablemente actuaba de acuerdo con el agente de Rothschild, y que resultó ganador ${ }^{130}$.

En diciembre de 1851 concluía el plazo de dos años durante los cuales estuvo en vigor el último contrato firmado con los Rothschild. Bravo Murillo, presidente del Consejo y titular de Hacienda desde enero, anunciaba la venta en pública subasta de 72.000 quintales a 1.300 pesos. Una parte estaba depositada en las atarazanas de Sevilla y correspondía a las partidas que no se habían vendido esos dos años conforme a los términos de la contrata de 1850 . El resto lo producirían las minas hasta el 6 de enero de 1856, fecha en que finalizaría la contrata ${ }^{131}$. A falta de licitadores, el día 7 de enero de 1852 la subasta quedó desierta. Esta vez los Rothschild habían decidido no concurrir. Estaban encontrando muchas dificultades para vender el mercurio adquirido en 1850 , y seguramente lamentaban no haber seguido los consejos de Lionel Davidson, su

127 Desde 1856 se convirtieron en los agentes de O'Shea \& Co. en Londres y se hicieron cargo del cobre que éstos remitían para la venta en el mercado británico, así como de la compra de rieles y otros productos industriales por cuenta de O'Shea. A través de Baring, los O'Shea adquirieron títulos de las deudas extranjeras negociadas en Londres.

${ }_{128}$ Los bienes de la Orden se pusieron en venta por Real Decreto de 1 de mayo de 1848 . Sobre esta deuda, Fernández ACHA, V.: Datos básicos para la Historia Financiera de España 1850/1954, vol. II, La Deuda pública. Madrid, Instituto de Estudios Fiscales, 1976, p. 21.

$129 \mathrm{BBA}, \mathrm{HC} 4.8 .6,3$ de noviembre de 1851. Toda la correspondencia de este mes gira en torno a esta negociación.

130 BBA, HC4.8, 25 de junio de 1852.

131 Martín Martín, V.: Los Rothschild..., pp. 246 y ss. 
agente en California, que desde 1848 les venía advertido de que cualquier nuevo contrato con España era arriesgado. A fines de 1850 los escollos iniciales con que había tropezado la explotación de Nuevo Almadén se habían superado y las nuevas minas producían ya suficiente mercurio para abastecer el mercado mexicano en su totalidad. Davidson se quejaba entonces de que muchas de las compañías mineras a las que antes abastecía estaban firmando contratos con Nuevo Almadén. El año, se lamentaba, cerraba con pobres resultados ${ }^{132}$. Estimaba que en 1851 Nuevo Almadén produciría más de 20.000 frascos, es decir 9.000 quintales, a unos 20 pesos ( 400 reales) el quintal; como el Gobierno español exigía por el mercurio de Almadén un mínimo de 1.300. La conclusión era obvia: "No tenemos posibilidad de competir con ellos (con los propietarios de Nuevo Almadén) en el mercado (...) los precios se han sostenido artificialmente a través de nuestro monopolio y ahora deben mantenerse mediante un acuerdo que actúe sobre el mercado como si aún existiese el monopolio» ${ }^{133}$.

Trabajando en ese sentido, a fines de diciembre de 1850 Davidson lograba llegar a un arreglo con los propietarios de Nuevo Almadén: durante cuatro meses las ventas en México se harían en común, correspondiendo a los Rothschild un tercio de las mismas. Se entendía que este arreglo sería preludio de un acuerdo general que abarcaría la totalidad de los mercados, reservando a los Rothschild un tercio del americano y mexicano, dos tercios de los restantes ${ }^{134}$. Pese a los propósitos, el acuerdo definitivo sobre reparto de mercados no fue posible. Sabemos que las negociaciones emprendidas en Londres por uno de los socios de la firma inglesa Antony Gibbs \& Sons, accionistas de Nuevo Almadén, con Lionel de Rothschild fracasaron ${ }^{135}$. De modo que el arreglo de fines de diciembre de 1850 fue prorrogándose hasta octubre de 1851. Entonces los dueños de las minas de California decidieron suspenderlo y abandonar toda negociación sobre reparto de mercados ${ }^{136}$. Gracias al acuerdo provisional el precio del mercurio en Nueva España se había mantenido a 120 pesos el quin-

132 RAL, XI/38/77/A, L. Davidson a N.M. Rothschild, 1 de noviembre de 1850.

133 Ibíd., 3 de diciembre de 1850.

134 RAL, XI/38/77A, L. Davidson a N.M. Rothschild, 3 de diciembre de 1850. También SÁNCHEZ MOLERO, L.M. se hace eco de estas negociaciones, op. cit., p. 88.

135 RAL, XI/38/77A, L. Davidson a N.M. Rothschild, sin fecha (marzo de 1851).

136 Lionel de Rothschild no estaba dispuesto a admitir un reparto del mercado europeo, pero quería mantener una participación en el americano, pretensión que Davidson juzgaba imposible. El 9 de mayo de 1852 éste anunciaba que los primeros cargamentos enviados a Londres estaban de camino: "pronto tendrá la guerra en su propia casa y estará en Europa tan a la merced de Nuevo Almadén como he estado yo aquí estos doce meses", RAL, XI/38/77B. Según los datos estadísticos proporcionados por SÁNCHEZ MOLERO, Memoria..., p. 66, en 1852 se importaron, efectivamente, en Inglaterra cerca de 2.500 quintales procedentes de México.

Ignoramos si esta situación cambió con posterioridad, y si los Rothschild llegaron a adquirir intereses o a controlar Nuevo Almadén. NADAL, J.: El fracaso..., p. 111, indica que en 1867 los directores de Nuevo Almadén, inspirados por los banqueros israelitas, propusieron al Gobierno español arrendar Almadén. No he encontrado ninguna evidencia en el Archivo Rothschild. 
tal por espacio de un año. Poco después se precipitaba, situándose en torno a 50 , llegando incluso a 45 pesos. Posteriormente se elevó a 70 pesos, una vez que Balton Barron, uno de los socios de Nuevo Almadén, adquirió la propiedad de la mina (véase más arriba la nota 96).

A falta de licitador, tras la subasta de enero de 1852 el Gobierno se encontraba en una situación peor que la de dos años atrás: ahora la concurrencia de Nuevo Almadén había dejado de ser una amenaza convirtiéndose en realidad; además, los Rothschild tenían importantes existencias de la contrata de 1850 sin vender. Buscando una solución, el 3 de marzo de 1852 Bravo Murillo firmó un contrato con los Rothschild para que éstos se ocuparan de vender mercurio por cuenta propia y del gobierno en idénticas proporciones, es decir para la venta del azogue en participación por cuenta del Gobierno. El convenio funcionaba dè siguiente modo: realizada una oferta para la compra de un determinado número de botellas en Londres, la propuesta se remitía a la Comisión Española de Hacienda en aquella ciudad y cada una de las partes proporcionaba la mitad del mercurio. Sobre dicha venta los Rothschild recibían una comisión del 1 por 100 . La misma regla se aplicaba a las ventas realizadas en España, sobre las cuales una comisión similar era concedida por Rothschild. Dado que el mercurio que se vendía en España representaba una cantidad muy inferior, el arreglo resultaba mucho más ventajoso para los Rothschild ${ }^{137}$. El Gobierno y sus banqueros tenían intereses opuestos: los Rothschild, con existencias de contratas anteriores, procuraban obtener los mayores precios, incluso a costa de limitar las ventas; el Gobierno, por el contrario, aspiraba a compensar la caída de beneficios por quintal aumentando las ventas ${ }^{138}$.

El arreglo con Rothschild resultaba por tanto muy insatisfactorio, y Bravo Murillo no dejó de buscar otras soluciones. Conocida la relación amistosa que vinculaba a Enrique O'Shea con Balton Barron, el socio mayoritario de la Compañía de Nuevo Almadén, en octubre de 1852 el ministro pedía a O'Shea que procurase que Barron acudiera a Madrid para llegar a algún acuerdo o que le autorizase a actuar en su nombre. O'Shea había mantenido correspondencia con Barron, sabía que había existido un acuerdo con Rothschild y creía que un entendimiento para la venta del mercurio no sería difícil ${ }^{139}$. Mientras intentaba

137 BBA, HC4.86, O'Shea a BB, 2 de marzo y 16 de junio de 1852.

138 SÁNCHEZ MOLERO, L.M.: Memoria..., p. 55.

139 BBA, HC4.8.6, O'Shea a BB, 23 de octubre de 1852. Próximo el vencimiento del contrato con Rothschild se escribió a Barron. Parece que el Gobierno le llegó incluso a ofrecer que se hiciese cargo del mercurio de Almadén. Barron remitió a Madrid ciertas propuestas cuyo contenido no conocemos. Sin embargo, por razones que ignoramos, en Madrid se decidió romper las negociaciones, amenazándose a Barron — según indicaba Davidson a los Rothschild- con que le obligarían a cerrar. Barron, contrariado, habría asegurado a Davidson en una de sus entrevistas que demostraría al Gobierno que podía impedirle vender en el mercado mexicano. Cualquier posibilidad de entendimiento entre el Gobierno español y Barron había desaparecido. Por esta razón, cuando a lo largo 
entenderse con los propietarios de Nuevo Almadén, Bravo Murillo procuraba llegar un arreglo con Baring. En el otoño de 1852 aseguraba a $\mathrm{O}^{\prime}$ Shea que no quería tener nada que ver con los Rothschild, que habían logrado imponer unas condiciones que él no estaba dispuesto a padecer. Necesitaba 280.000 libras para pagar el dividendo de enero y deseaba que los Baring le hiciesen alguna propuesta basada en la entrega con carácter de garantía de 42.000 botellas de mercurio y de cierta cantidad de pagarés del Tesoro. Como. Mon seguía insistiendo en fijar un precio mínimo de venta, para animar a los Baring O'Shea recalcaba que los pagarés estaban siendo aceptados incluso por las casas más tímidas, siempre que se les permitiera un descuento. Recordaba que desde $1845 \mathrm{ni}$ uno solo había sido protestado o devuelto. Atendiendo a los deseos de Bravo Murillo, O'Shea elaboró unas bases que fueron remitidas a Londres ${ }^{140}$. Los Baring se comprometían a anticipar los 28 millones de reales contra pagarés del Tesoro a un 6 por 100 de descuento. Obtendrían en garantía el azogue existente en Londres y Sevilla, y el que se produjese hasta que se hubiese verificado la liquidación de los pagarés. Los Baring se encargarían de la venta del mercurio. La caída del Gabinete en diciembre de 1852 interrumpió esta negociación.

Los gobiernos posteriores procuraron también estrechar los vínculos con los Baring. Es importante recordar que fueron éstos los escogidos para realizar la conversión de la Deuda proyectada por el ministro de Hacienda Alejandro Llorente en $1853^{141}$. Efectivamente, estuvieron a punto de hacerse cargo de la negociación de un empréstito español en Londres por importe de 9,5 millones de esterlinas. De hecho, el 12 de marzo habían firmado un contrato con José Salamanca, que para ello se había desplazado a la capital británica en representación del Gobierno ${ }^{142}$. El empréstito tenía por finalidad consolidar 300 millones de pesetas de deuda flotante, transformándolos en títulos de la deuda del 3 por 100. Con objeto de lograr la apertura de la Bolsa de Londres, cerrada a las emisiones españolas desde la conversión realizada en 1851 por Bravo Murillo, se destinaba parte del empréstito a dar satisfacción a los disgustados tenedores de la deuda española: un 10,5 por 100 del importe total se emplearía en resarcirles de parte de las pérdidas de capital ocasionadas por el arreglo de Bravo Murillo. Para hacerse cargo de la operación, los Baring exigieron que el arreglo

\footnotetext{
de 1853 y 1854 Lionel de Rothschild insistía en que Davidson procurase un acuerdo, éste contestaba que ya no era posible, RAL, XI/38/77B, 2 de diciembre de 1853, y XI/38/78A, 1 de agosto de 1854 .

140 BBA, HC4.8.6, O'Shea a BB, 23 de octubre y 10 de noviembre de 1852.

141 Sobre el proyecto de ley de arreglo de la deuda puede consultarse GoNZALO Y GonZÁLEZ, L.: El Tesoro público y la Caja General de Depósitos (1852-1868), Madrid, Instituto de Estudios Fiscales, 1981, pp. 22 y 223, así como SANTILLÁN, R.: Memorias, 1808-1856, Madrid Tecnos / Banco de España, 1996, pp. 380-382.

142 BBA, HC48.16, Instrucciones de SM. con arreglo a las cuales se ba de verificar la negociación de los títulos del 3 por 100 para la que ha sido autorizado Salamanca por Real Orden de esta fecha, 18 de febrero de 1853. Incluye también un ejemplar del contrato celebrado en Londres entre Salamanca y Baring Brothers, fechado el 12 de marzo de 1853.
}

Hispania, LXIII/1, núm. 213 (2003) 255-294 
fuese aceptado por el Committee of the Spanish Bondholders y que las Cortes sancionasen la operación ${ }^{143}$. El proyecto de ley que Llorente remitió a las Cortes en abril de 1853 no fue siquiera discutido, ya que al día siguiente éstas fueron suspendidas. De haberse ocupado de la conversión, los Baring hubieran adquirido, indudablemente, una posición prominente sobre las finanzas españolas.

El 14 de abril de 1853 el conde de Lersundi sustituyó al conde de Alcoy en la Presidencia del Consejo de Ministros. Bermúdez de Castro ocupó la cartera de Hacienda. Juzgado por $\mathrm{O}^{\prime}$ Shea, el nuevo ministro de finanzas era uno de los hombres de negocios más hábiles del país. En las Cortes de 1850 había denunciado con pasión el monopolio ejercido por los Rothschild, a quienes responsabilizaba de encarecer innecesariamente el precio del azogue sin beneficio alguno para el Tesoro ${ }^{144}$. Ahora, desde el Ministerio, parecía estar bien dispuesto a transferir el negocio a los Baring y a adaptarse a las transformaciones que se habían operado en el mercado. Se conformaría con obtener beneficios moderados y permitiría la venta a un precio más reducido. Los Rothschild, reaccionaron de inmediato para neutralizar cualquier movimiento favorable a los Baring. El banquero Ignacio Bauer — sucesor de Weisweiller en su agencia de Madrid- presentó entonces una propuesta ofreciéndose a proseguir con el anticipo de 200.000 esterlinas a un 5 por 100 de interés anual, y a hacerse cargo de las ventas de mercurio con comisión del 1 por 100. En cualquier caso, antes de que Bermúdez de Castro llegase a adoptar una decisión, el 20 de junio concluía su breve paso por el poder ${ }^{145}$. De modo que en marzo de 1854 al vencer el contrato firmado con los Rothschild en 1852, sin recursos para cancelar la deuda con sus acreedores, el Gobierno se vio obligado a contratar la venta en comisión en ciertas condiciones; ligando este convenio a nuevos anticipos. El Gobierno continuaría limitando sus ventas al mercado interior y la casa Rothschild al exterior ${ }^{146}$.

En julio de 1854 triunfaba la revolución que llevó a los progresistas al poder. José Manuel Collado, un conocido y respetado banquero madrileño, fue designado para ocupar el Ministerio de Hacienda ${ }^{147}$. Había sido asentista del Estado para el suministro del Ejército durante la Guerra Carlista y era uno de los mayores accionistas del Banco de San Fernando, entidad en la que había ocupado puestos de responsabilidad. Procedente del ala puritana del moderantismo e incorporado al progresismo, se proponía introducir importantes modificaciones en diversos aspectos de la Hacienda. En agosto, cuando quedaban unos meses para que venciera el contrato con la casa Rothschild, encargaba a O'Shea que de forma muy reservada se pusiera en comunicación con los Ba-

143 BBA, LB, núm. 24, p. 78, 9 de marzo de 1853.

144 DSCD, núm. 43, 21 de enero de 1850, p. 1052.

145 BBA, HC4.8.6, O'Shea a BB, 1 de julio de 1853. Sobre las realizaciones de Bermúdez de Castro en Hacienda, SANTILLÁN, R.: Memorias..., pp. 383-385.

146 ZARRALUQUi, J.: Los almadenes..., p. 705. Real Orden de 1 de mayo de 1854.

${ }_{147}$ Acerca de este personaje, relativamente desconocido, alguna referencia en TORTELLA, G.: Los orígenes..., p. 351 y TEDDE, P.: El Banco..., pp. 92, 123, 191, 264, 299 y 300. 
ring. Al entrar en el Ministerio - indicaba - se había encontrado un contrato oneroso para el Tesoro y degradante para el Gobierno que se veía comprometido a limitar sus ventas mercado interior quedando el extranjero reservado a los Rothschild. Conforme a una de sus cláusulas, el contrato de venta en comisión se prorrogaría hasta que la casa se hubiese reembolsado de sus anticipos. El ministro quería devolver las 270.000 libras adeudadas entonces, cuya garantía eran 40.000 frascos de mercurio. Estaba convencido de que con el asunto en manos de los Baring se podría llegar a algún arreglo con los directores de las minas de Nuevo Almadén y de que Baring Brothers actuarían como agentes para la venta del mercurio sin ulteriores miras ${ }^{148}$. Pero a esas alturas la casa Baring no mostraba ya entusiasmo alguno por la aventura del azogue. La experiencia de las negociaciones con el Gobierno — se quejaba Thomas Baring en cierta ocasión- les hacía pensar que cualquier propuesta que hicieran sería utilizada por éste para obtener ventajas en sus negociaciones con terceros ${ }^{149}$. En cualquier caso, correspondía al Gobierno decidir si estaba o no conforme con los arreglos existentes y elevarles una propuesta que estudiarían. Desde luego, las circunstancias políticas no parecían las más adecuadas para inspirar confianza y la idea se abandonó sin haber llegado a acuerdo alguno. El contrato con Rothschild se prorrogó hasta fines de $1855^{150}$.

Los beneficios producidos por este sistema de venta fueron escasos y no faltaron, como se ha visto, esfuerzos por saldar las cuentas con Rothschild ${ }^{151}$. A pesar de ello, no fue hasta junio de 1856 cuando Pedro Salaverría lograba cancelar la deuda contraida, reintegrando los anticipos y recuperando el mercurio. Poco después, la Real Orden de 15 de octubre de 1856 dispuso la venta directa del azogue a través de la Comisión Financiera Española en Londres. En aquellos años de venta directa la Hacienda se benefició de una mejora de los precios del mercurio, que pasaron de los 616 reales fijados en la contrata de 1855 a 1.051 entre 1858 y 1866. Además, aumentó el volumen de las ventas que se habían paralizado en la etapa anterior ${ }^{152}$. En vista de estos resultados, Chastagnaret, ocupándose recientemente de estos problemas, concluye que Almadén se benefició de la ruptura con Rothschild ${ }^{153}$.

Durante los años de venta directa no faltaron los anticipos al Tesoro con garantía de mercurios facilitados por esta favorable evolución experimentada por el mercado del azogue en el marco de una tendencia expansiva de la econo-

148 BBA, HC4.8.6, 20 de agosto de 1854, confidencial. Los Baring tenían buenas relaciones con Antony Gibbs \& Sons, uno de los accionistas de Nuevo Almadén.

149 BBA, LB, núm. 26 p. 217, 29 y 30 de agosto de 1854 .

150 BBA, HC4.8.6, O'Shea a BB, 7 de noviembre de 1854 y ZARrAluQUi, J.: Los almadenes..., p. 705.

151 NADAL, J.: El fracaso..., p. 11.

152 ZARRALUQUI, J.: Los almadenes..., p. 706.

153 Chastagnaret, G.: L'Espagne, puissance minière dans IEurope du XIXe siècle, Madrid, Casa de Velázquez, 2000.

Hispania, LXIII/1, núm. 213 (2003) 255-294 
mía. Entre todos ellos nos interesa particularmente el de 150.000 libras realizado a fines de 1864 por Murrieta \& Co. de Londres. El anticipo quedaba garantizado por la hipoteca de los 17.500 frascos de mercurio en manos de la Comisión Financiera Española, que seguiría encargada de realizar la venta como hasta entonces. La Comisión remitiría semanalmente a Murrieta el producto de las ventas ${ }^{154}$. La casa Baring había tomado para sí la mitad del negocio y adelantaba a Murrieta las 75.000 libras correspondientes ${ }^{155}$. Transcurridos los seis meses en que el anticipo debía haber sido devuelto, en mayo de 1865 fue prorrogado por primera vez, situación que se prolongó hasta septiembre de 1866. Al sobrevenir la crisis de 1866, las necesidades del Tesoro y el deterioro de la situación financiera pusieron nuevamente al Tesoro en manos de sus tradicionales banqueros. N.M. Rothschild \& Sons de Londres se encargó de la venta en comisión de 50.000 frascos de azogue que servían de garantía a un anticipo de 250.000 libras esterlinas. A partir de entonces, y hasta bien entrado el siglo XX, retuvieron el monopolio de la venta del mercurio español. Los Baring abandonaban definitivamente la escena, siendo probablemente una de sus últimas intervenciones un importante anticipo que junto a Antony Gibbs hicieron al Banco de España entre 1864 y 1865 .

${ }_{154}$ Una copia del contrato firmado entre Cristóbal Murrieta y José Barrojo, representante del Gobierno en Londres, en BBA, 8.4.23. El interés sería equivalente a la tasa mínima de descuento del Banco de Inglaterra, entonces del 9 por 100 , pero en ningún caso inferior al 5 por 100 . Percibirían, además, cada tres meses una comisión del 0,5 por 100 sobre las cantidades por las que el Gobierno resultase acreedor.

15s BBA, 8.4.23, 13 de noviembre de 1864, Murrieta a BB.

Hispania, LXIII/1, núm. 213 (2003) 255-294 